\title{
EXPERIMENTAL STUDY OF STEEL SHOT AND LEAD SHOT TRANSFORMATION UNDER THE ENVIRONMENTAL FACTORS
}

\author{
Vladimir Lisin ${ }^{1}$, Valentina Chizhikova ${ }^{2}$, Tatiana Lubkova ${ }^{3}$ and Daria Yablonskaya ${ }^{3 *}$ \\ ${ }^{1}$ The Russian Shooting Union, 119270 Moscow, Russia; shooting@ shooting-russia.ru (V.L.); \\ ${ }^{2}$ LLC "RUMELKO”, 123242 Moscow, Russia, chizhikova.v.m@gmail.com (V.C.); \\ ${ }^{3}$ Faculty of Geology, Lomonosov Moscow State University, GSP-1, Leninskie Gory, 119991, Moscow, Russia; \\ tanyalubkova@gmail.com (T.L.), daria.yablonskaya@gmail.com (D.Y.) \\ *correspondence: daria.yablonskaya@gmail.com (D.Y.)
}

\begin{abstract}
This paper presents the results of an experimental study of the patterns of steel and lead shot transformation under the impact of environmental factors (two types of shot exposed alone and in combination with each other). The analyzed environmental factors include atmospheric precipitation of various acidity and soil solutions ${ }^{*}$ with a higher content of organic acids. This research demonstrated that steel shot is characterized by a high transformation rate that is an order of magnitude higher on average than the transformation rate of lead under the same conditions (Lisin et al., 2020). The prevalence of the suspended iron form (excluding the interaction with organic acids) presents risks for such environmental components as soils and sediments and may be hazardous to the ambient air and natural waters in case of wind erosion and surface runoff from the catchment area. Furthermore, the joint presence of steel and lead shot mutually accelerates the corrosion of both metals, thus increasing the environmental risks.
\end{abstract}

Key words: ammunition, environmental factors, transformation of lead shot, transformation of steel shot

\section{INTRODUCTION}

The European Chemicals Agency (ECHA) has recently prepared a proposal to introduce sweeping restrictions on the use of lead in ammunition for hunting and outdoor sports shooting and fishing tackle (ECHA, 2021). Earlier, Regulation (EU) 2021/57 (2021) banned lead ammunition in or around wetlands; the ban will enter into force in 2023. The restrictions proposed by ECHA are introduced according to the Strategic Approach to International Chemicals Management and Sound Management of Chemicals and Waste Beyond 2020 (UNEP, 2007).

The motivation of introduced restrictions is related to the public discussions of risks presented by lead ammunition to wildlife, environment, and health (Scheuhammer and Norris, 1996; Pain et al., 2010; Bellinger et al., 2013; Pain et al., 2015; Arnemo et al., 2016; Pain et al., 2019), and transition to non-lead ammunition (Thomas and Guitart, 2013; Kanstrup and Thomas, 2020; Open Letters, 2018, 2020; Thomas et al., 2021).

\footnotetext{
* Soil solutions are the liquid phase of soils that includes soil water and contains dissolved salts, organomineral and organic compounds, gases and the finest colloidal sols (Popov V.V., 2020)
} 
It is known that some of the other metals (cobalt, copper, nickel, tungsten, zinc) that can be used as an alternative for lead in ammunition are characterized by biotoxicity (Grandy et al., 1968; Levengood, 1999; Bardack et al., 2014; Paulsen and Sager, 2017; Thomas, 2016, 2019).

Steel is often viewed as the most preferred alternative to lead in ammunition and fishing tackle because it is available in large amounts, the production costs are not high, and iron is also considered not to be toxic for humans and wildlife (ECHA (Annex C), 2021). However, the disputable claim of the non-toxic nature of iron needs to be clarified because reliable sources from the medical community prove that iron overload can be dangerous for the human body. The International Statistical Classification of Diseases and Related Health Problems maintained by the WHO (ICD-10 Version:2019) contains a group of human health conditions related to the excessive accumulation of iron in organs and tissues (ICD-10: E83.1. Disorders of iron metabolism), resulting in the release of free iron ions into the blood plasma, the extracellular space and inside cells. Free iron activates the free-radical oxidation of biological membrane lipids that is accompanied by toxic damage of proteins and cell structures (Lukina and Dezhenkova, 2015; Orlov, 2020) and is also a potential energy source for pathogens (Orlov, 2020). The prime targets for iron toxicity are the liver, endocrine system, and myocardium (Tarasova and Teplyakova, 2012). Therefore, according to the medical community, iron overload is associated with cytotoxicity and affects the human immune system.

Since lead shot use has been partially or totally banned in 23 European countries (Mateo and Kanstrup, 2019), interested users switch to non-lead ammunition (mostly steel). As a result, in the soil of active shooting areas (hunting lands, shooting ranges, and shooting complexes where metallic lead in the soils) are obtained accumulation of steel shot and its fragments, and supposed to a significant concentration of steel shot in such soils.

The processes of lead shot transformation under the atmospheric and soil corrosion factors are well-known (SAAMI, 1996; Lin, 1996; Rooney et al., 1999; Cao et al., 2003; Dermatas et al., 2006; Rauckyte et al., 2009; Lewis et al., 2011; Mera et al., 2015; Okkenhaug et al., 2016; Kelebemang et al., 2017; Lisin et al., 2020). Some studies (Schwarz et al., 2015; Fäth et al., 2018; Fäth and Göttlein, 2019) analyzed the potential risks for aquatic ecosystems in case of the steel ammunition presence. There was studied the interaction between steel shot and water originating from siliceous and calcareous bedrock under aerobic and anaerobic conditions and between steel shot and artificial freshwater for the culture of zooplankton $(\mathrm{ADaM})$. The risks of corrosive change of steel ammunition in a mineral substrate (Fäth and Göttlein, 2017) and corrosive change of the steel and lead ammunition in soil (Hurley, 2004, 2013) have been studied quite limitedly.

This article presents the results of an experimental study of the transformation of steel shot exposed alone and in combination with a lead shot under the main environmental factors: atmospheric precipitation of various acidity and model soil solutions.

A dynamic study of steel shot and lead shot transformation was conducted by modeling the effect of various extreme environmental factors in conditions of continuous impact and cyclical update of factors. The experiment involved three sample groups: steel shot exposed alone, a 1:1 mixture of steel and lead shot, and lead shot exposed alone. 
This experimental study represents the initial phase of monitoring the transformation of steel shot, exposed alone, and combined with lead shot, in soils.

\section{MATERIALS AND METHODS}

The transformation of steel shot and lead shot exposed alone and in combination was studied under the extreme conditions of permanent humidification in a laboratory experiment.

The experimental work included performing cyclical processing of shot samples with solutions modeling the environmental factors, subsequent analysis of interaction solutions, and studying the shot surface using scanning electron microscopy.

\subsection{Shot collection}

The experiment for studying shot transformation rate was performed using three groups of samples: steel shot exposed alone, a 1:1 mixture of steel and lead shot, and lead shot exposed alone. The study used commercial steel shot (2.5 mm diameter) and lead shot \#7.5 (2.4 mm diameter) for sports shooting. According to production specifications, the following residual elements are present in steel shot: $\mathrm{C}(0.6-1.0 \%), \mathrm{Si}(0.7-1.2 \%), \mathrm{Mn}(0.5-1.0 \%), \mathrm{S}$ (up to $0.07 \%$ ), $\mathrm{P}$ (up to $0.09 \%$ ). The main residual elements in steel shot are $\mathrm{Sb}(4-6 \%), \mathrm{Sn}(0.1-$ $0.2 \%)$, As (0.2\%), $\mathrm{Cu}(0.02 \%), \mathrm{Ag}(0.002 \%)$, and $\mathrm{Zn}(0.001 \%)$.

\subsection{Experimental model}

The following environmental factors were considered:

- atmospheric precipitation with normal acidity - actual $\mathrm{Ca}-\mathrm{HCO}_{3}$ rainwater with $\mathrm{pH}$ $6.1 \pm 0.2$ and specific electrical conductivity of $27 \pm 3 \mu \mathrm{S} / \mathrm{cm}$ (hereinafter, "atmospheric precipitation");

- $\quad$ atmospheric precipitation with increased acidity - an aqueous solution of a high-purity nitric and sulfuric acid mixture with $\mathrm{pH} 4.0 \pm 0.1$ and specific electrical conductivity of $30 \pm 2$ $\mu \mathrm{S} / \mathrm{cm}$ (hereinafter, "acid precipitation");

- $\quad$ soil solutions - an ammonium acetate buffer solution (5.4 $\mathrm{ml}$ of acetic acid glacial, 3.75 $\mathrm{ml}$ of $25 \%$ ammonia solution), $\mathrm{pH} 4.8 \pm 0,1$ specific electrical conductivity of $4500 \pm 100 \mu \mathrm{S} / \mathrm{cm}$, this solution can also be considered as an approximate model of wetland environment.

The interaction was modeled with a 1:20 ratio shot/solution $(5 \mathrm{~g}$ of shot, $100 \mathrm{ml}$ of a solution) at room temperature $\left(25 \pm 2^{\circ} \mathrm{C}\right)$. Each processing cycle of interaction between a shot and a solution lasted for four days. Then the solution was replaced entirely. Twenty-five cycles of processing were conducted over the total experiment time of 100 days.

The main physical and chemical properties ( $\mathrm{pH}$ and specific electrical conductivity) and the content of suspended and dissolved forms of shot metals (iron and lead) were monitored in the solutions obtained after each processing cycle.

\subsection{Analytical methods}

The potentiometric $\mathrm{pH}$ determination was carried out by "Expert 001" (Econix Expert Ltd., Moscow, Russia) with measuring glass electrode (type ESL-43-07) and control reference electrode silver/silver chloride electrode $\mathrm{Ag} / \mathrm{AgCl} / \mathrm{KCl}$ (type EVL-1M). Calibration standard buffer solutions $(1.08 ; 3.56 ; 7.40 ; 9.18$ units) were used.

Specific electrical conductivity was evaluated by HM Digital COM80 (HM Digital, Inc., South Korea), calibration solutions (10, 84, $1413 \mu \mathrm{S} / \mathrm{cm}$, OHAUS Corporation) were used. Measurement range 0-9990 $\mu \mathrm{S} / \mathrm{cm}$. 
The interaction solutions were filtered using Swinex filter holders (Millipore) and cellulose acetate membrane filters ( $\varnothing 0.45 \mu \mathrm{m}$, Vladipore) to separate various forms of elements. The filters with suspended metals were decomposed using a high-purity nitric and hydrochloric acid mixture. Iron and lead content in solutions were determined using atomic absorption spectroscopy (AAS; ContrAA®700, Analytik Yena) and inductively coupled plasma mass spectrometry (ICP-MS; ELEMENT2, Thermo Finnigan). The instruments were calibrated using mono element standards of iron and lead ions and a multi-element standard (High Purity Standards).

The shot surface was studied using Scanning Electron Microscopy (SEM) both initially and after 15 cycles of interaction between shot samples and solutions. The microstructure analysis was conducted both without preliminary preparation and on cross-sectional metallographic specimens. Metallographic specimens were prepared by embedding in an electrically conductive resin using hot mounting (CitoPress-30 mounting press, for steel shot) and embedding in a two-component cold cure polymer (for the lead shot) with subsequent grinding (on a Tegramin-30 machine) and final polishing with a colloidal $\mathrm{SiO}_{2}$.

The morphology of the surface and near-surface sample layers was analyzed without preliminary preparation using a dual-beam focused ion beam scanning electron microscope (DB FIB-SEM; Thermo Scientific Scios 2 DualBeam equipped with ETD and CBS detectors). The electrons were accelerated at $10-20 \mathrm{kV}$, beam current range 0.1-1.6 $\mathrm{nA}$, the working distance comprised between 6.2 and $7.3 \mathrm{~mm}$. The cross-section of near-surface layers was studied using an ion beam microscope to make a sample's local 20-30- $\mu \mathrm{m}$-deep cut. Before creating a cross-section, the sample was coated with a thin protective layer $(1-3 \mu \mathrm{m})$ of organometallic platinum using a gas injection system (Pt-GIS). The content and distribution of chemical elements over the surface and the cross-section of near-surface layers of samples were conducted without preparation using a Bruker microanalysis system with XFlash EDS detector.

The metallographic specimens were analysed using a scanning electron microscope (SEM; Tescan Mira 3 equipped with SE and 4Q BSE detectors). The operation conditions were $20 \mathrm{kV}$ accelerating voltage and 13-16 mm working distance. Additionally, chemical characterizations of metallographic specimens were determined by an energy-dispersive x-ray detector (EDS; Oxford Instruments).

The SEM data of element concentration ( $>0.05$ at $\%$ ) was calculated using ZAF correction.

\section{RESULTS AND DISCUSSION}

\subsection{The characteristics of shot samples}

According to the electron microscopy results, initially, before any interaction with environmental factors, the surface of steel and lead shot is covered by a respective oxide coating with a thickness of $0.5-1.0 \mu \mathrm{m}$.

It has been detected that lead shot contains antimony with a concentration of up to $5 \mathrm{wt} \%$, which is mainly present along the edges of lead grains in the eutectic phase of the molten $\mathrm{Pb}-\mathrm{Sb}$ mixture. The near-surface layer of the lead shot has a porous structure, with a cross-sectional diameter of $1-5 \mu \mathrm{m}$. 
A steel shot sample has micro-cracks running inward from the surface. These cracks may accumulate corrosive media and cause a local displacement of the surface's electrode potential due to the stress concentration, increasing the material's corrosion rate. The micro-cracks surface is weakly oxidized, indicating that they are formed during the shot manufacturing process. The large, elongated grains in the near-surface shot layers form discontinuities that contribute to aggressive media corrosive processes.

\subsection{The transformation of steel shot and lead shot under environmental factors}

The results of the chemical analysis of interaction solutions after each cycle of processing are presented in Tables S1-S3 (Supplementary Material), and the calculated ratios of dissolved and suspended forms for various interaction scenarios are shown in Table 1. Quantitative assessment of shot destruction was based on calculating the metal loss per shot unit mass (mg $\mathrm{Fe} / \mathrm{g}$ of steel shot, mg Pb/g of lead shot). The calculations were made using the measured concentration of elements in interaction solutions after each cycle of processing, the volume of solutions and mass of shot, and complemented by weighing the steel shot and lead shot to measure the mass loss (Table 2).

Table 1. Iron and lead forms in interaction solutions

\begin{tabular}{|c|c|c|c|c|c|c|}
\hline \multirow{2}{*}{$\begin{array}{l}\text { Environmental } \\
\text { factor }\end{array}$} & \multirow[t]{2}{*}{ Shot forms } & \multirow[b]{2}{*}{ Item } & \multirow{2}{*}{$\begin{array}{c}\text { Cycles of } \\
\text { processing } \\
\text { (solution No.) }\end{array}$} & \multirow[b]{2}{*}{$\begin{array}{l}\text { Total element } \\
\text { content, ppm }\end{array}$} & \multicolumn{2}{|c|}{$\%$ of total content, on average } \\
\hline & & & & & Dissolved forms & $\begin{array}{l}\text { Suspended } \\
\text { forms }\end{array}$ \\
\hline \multirow{10}{*}{ 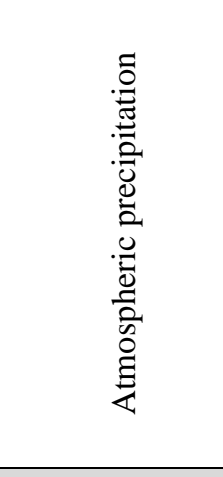 } & \multirow{2}{*}{ Steel shot ${ }^{1}$} & \multirow{2}{*}{$\mathrm{Fe}$} & $1-2$ & $7-14$ & 42 & 58 \\
\hline & & & $3-25$ & $46-80$ & $<0.1$ & $>99.9$ \\
\hline & \multirow{5}{*}{$\begin{array}{l}\text { A mixture } \\
\text { of steel and } \\
\text { lead shot }{ }^{2}\end{array}$} & \multirow{2}{*}{$\mathrm{Fe}$} & $1-2$ & $10-12$ & 12 & 88 \\
\hline & & & $3-25$ & $32-85$ & $<0.1$ & $>99.9$ \\
\hline & & \multirow{3}{*}{$\mathrm{Pb}$} & $1-3$ & $1.4-2.4$ & 14 & 86 \\
\hline & & & $4-15$ & $5.5-30$ & 2 & 98 \\
\hline & & & $16-25$ & $1.7-5.9$ & 4 & 96 \\
\hline & \multirow{3}{*}{ Lead $\operatorname{shot}^{1}$} & \multirow{3}{*}{$\mathrm{Pb}$} & $1-7$ & $0.9-1.6$ & 83 & 17 \\
\hline & & & $8-16$ & $2.8-5.1$ & 32 & 68 \\
\hline & & & $17-25$ & $1.2-2.2$ & 52 & 48 \\
\hline \multirow{10}{*}{ 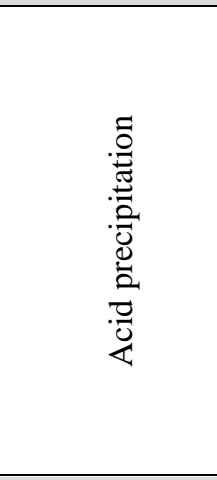 } & \multirow{2}{*}{ Steel shot ${ }^{1}$} & \multirow{2}{*}{$\mathrm{Fe}$} & $1-2$ & $2.6-22$ & 17 & 83 \\
\hline & & & $3-25$ & $48-87$ & 0.9 & 99.1 \\
\hline & \multirow{5}{*}{$\begin{array}{l}\text { A mixture } \\
\text { of steel and } \\
\text { lead shot }{ }^{2}\end{array}$} & \multirow{2}{*}{$\mathrm{Fe}$} & $1-2$ & $2.6-12$ & 0.4 & 99.6 \\
\hline & & & $3-25$ & $37-85$ & $<0.1$ & $>99.9$ \\
\hline & & \multirow{3}{*}{$\mathrm{Pb}$} & $1-3$ & $6.5-14$ & 23 & 77 \\
\hline & & & 4-11 & $19-45$ & 4 & 96 \\
\hline & & & $12-25$ & $3.2-12$ & 14 & 86 \\
\hline & \multirow{3}{*}{ Lead shot $^{1}$} & \multirow{3}{*}{$\mathrm{Pb}$} & $1-3$ & $16-29$ & 14 & 86 \\
\hline & & & $4-5$ & $5.0-7.3$ & 55 & 45 \\
\hline & & & $6-25$ & $5.0-7.9$ & 95 & 5 \\
\hline \multirow{6}{*}{ 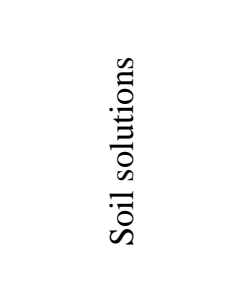 } & \multirow{2}{*}{ Steel shot ${ }^{1}$} & \multirow{2}{*}{$\mathrm{Fe}$} & $1-2$ & $129-498$ & 97 & 3 \\
\hline & & & $3-25$ & $343-885$ & 67 & 33 \\
\hline & \multirow{3}{*}{$\begin{array}{l}\text { A mixture } \\
\text { of steel and } \\
\text { lead shot }{ }^{2}\end{array}$} & \multirow{2}{*}{$\mathrm{Fe}$} & $1-2$ & $341-371$ & 99 & 1 \\
\hline & & & $3-25$ & $211-600$ & 80 & 20 \\
\hline & & $\mathrm{Pb}$ & $1-25$ & $9.4-26$ & 95.2 & 4.8 \\
\hline & Lead shot $^{1}$ & $\mathrm{~Pb}$ & $1-25$ & $193-488$ & 99.4 & 0.6 \\
\hline
\end{tabular}

${ }^{1} 5 \mathrm{~g}$ of shot, $100 \mathrm{ml}$ of a solution; ${ }^{2} 2.5 \mathrm{~g}$ of each type of shot, $100 \mathrm{ml}$ of a solution 
Table 2. Evaluation of shot mass loss due to the interaction with environmental factors

\begin{tabular}{|c|c|c|c|c|}
\hline $\begin{array}{l}\text { Environmental } \\
\text { factor }\end{array}$ & Shot forms & $\begin{array}{l}\text { The initial mass of a } \\
\text { shot sample part, } g\end{array}$ & $\begin{array}{c}\text { The mass of a shot } \\
\text { sample part after } 25 \\
\text { cycles of processing, } g\end{array}$ & Mass loss, $\%$ \\
\hline \multicolumn{5}{|c|}{ Steel shot } \\
\hline \multirow{2}{*}{$\begin{array}{l}\text { Atmospheric } \\
\text { precipitation }\end{array}$} & Exposed alone & \multirow{2}{*}{$0.330 \pm 0.001$} & $0.320 \pm 0.003$ & $3.0 \pm 1.0$ \\
\hline & In combination with $\mathrm{Pb}$ & & $0.315 \pm 0.005$ & $4.5 \pm 1.5$ \\
\hline \multirow{2}{*}{$\begin{array}{c}\text { Acid } \\
\text { precipitation }\end{array}$} & Exposed alone & \multirow{2}{*}{$0.330 \pm 0.001$} & $0.318 \pm 0.004$ & $3.6 \pm 1.2$ \\
\hline & In combination with $\mathrm{Pb}$ & & $0.312 \pm 0.004$ & $5.5 \pm 1.2$ \\
\hline \multirow{2}{*}{ Soil solutions } & Exposed alone & \multirow{2}{*}{$0.330 \pm 0.001$} & $0.240 \pm 0.008$ & $27 \pm 2$ \\
\hline & In combination with $\mathrm{Pb}$ & & $0.228 \pm 0.006$ & $31 \pm 2$ \\
\hline \multicolumn{5}{|c|}{ Lead shot } \\
\hline \multirow{2}{*}{$\begin{array}{l}\text { Atmospheric } \\
\text { precipitation }\end{array}$} & Exposed alone & \multirow{2}{*}{$0.415 \pm 0.001$} & $0.413 \pm 0.001$ & $<0.5$ \\
\hline & In combination with $\mathrm{Fe}$ & & $0.410 \pm 0.001$ & $1.2 \pm 0.3$ \\
\hline \multirow{2}{*}{$\begin{array}{c}\text { Acid } \\
\text { precipitation }\end{array}$} & Exposed alone & \multirow{2}{*}{$0.415 \pm 0.001$} & $0.413 \pm 0.001$ & $<0.5$ \\
\hline & In combination with $\mathrm{Fe}$ & & $0.408 \pm 0.002$ & $1.6 \pm 0.3$ \\
\hline \multirow{2}{*}{ Soil solutions } & Exposed alone & \multirow{2}{*}{$0.415 \pm 0.001$} & $0.365 \pm 0.008$ & $12 \pm 2$ \\
\hline & In combination with $\mathrm{Fe}$ & & $0.407 \pm 0.002$ & $1.9 \pm 0.5$ \\
\hline
\end{tabular}

Note: the mass of a shot sample part is obtained based on weighing five random pellets ten times

\section{Factor - Atmospheric precipitation}

When steel shot interacts with atmospheric precipitation, steel shot is oxidized, and interaction solutions are alkalized (due to the reduction of hydrogen ions). The final $\mathrm{pH}$ value of interaction solutions varied between 6.4 and 7.1. Except for the solution of $1^{\text {st }}$ processing cycle, the specific electrical conductivity remained more or less stable $(\sigma=20-30 \mu \mathrm{S} / \mathrm{cm})$.

Starting with the $3^{\text {rd }}$ cycle of processing, the iron content was between 46 and $80 \mathrm{mg} / \mathrm{l}$. Dissolved iron forms were only present in significant amounts during the early experiment phase (in the solutions of the $1^{\text {st }}$ and $2^{\text {nd }}$ cycle of processing, with the concentration of 2.8-6.4 $\mathrm{mg} / \mathrm{l}$ and total iron content of 7-14 mg/l). In later solutions, the content of dissolved iron forms did not exceed $0.05 \mathrm{mg} / \mathrm{l}$, and iron was present in interaction solutions in its suspended form (Table 1).

The assessment of iron loss was performed according to a cumulative system and showed that steel shot was constantly and gradually dissolving throughout the entire duration of its interaction with atmospheric precipitation (Fig. 1, a). Over the entire experiment period (100 days), the loss of iron due to the interaction with atmospheric precipitation was $2.8 \%$ of the initial steel shot mass when exposed alone. Therefore, the average rate of steel shot dissolution was $0.03 \%$ of the initial shot mass per day. The obtained results are consistent with the assessment of steel shot loss using the weight method (Table 2).

Secondary changes are visible on the shot surface during and after the interaction between steel shot and atmospheric precipitation (Fig. 2,a). According to the SEM data, a corrosion product coating with a thickness of 5-25 $\mu \mathrm{m}$ forms on the surface of steel shot, in areas with surface micro-cracks - with a thickness of up to 50 forms and more (Fig. 2, b). The main corrosion product is the friable iron oxides in the form of round-shaped submicron particles (Fig. 2,c). 


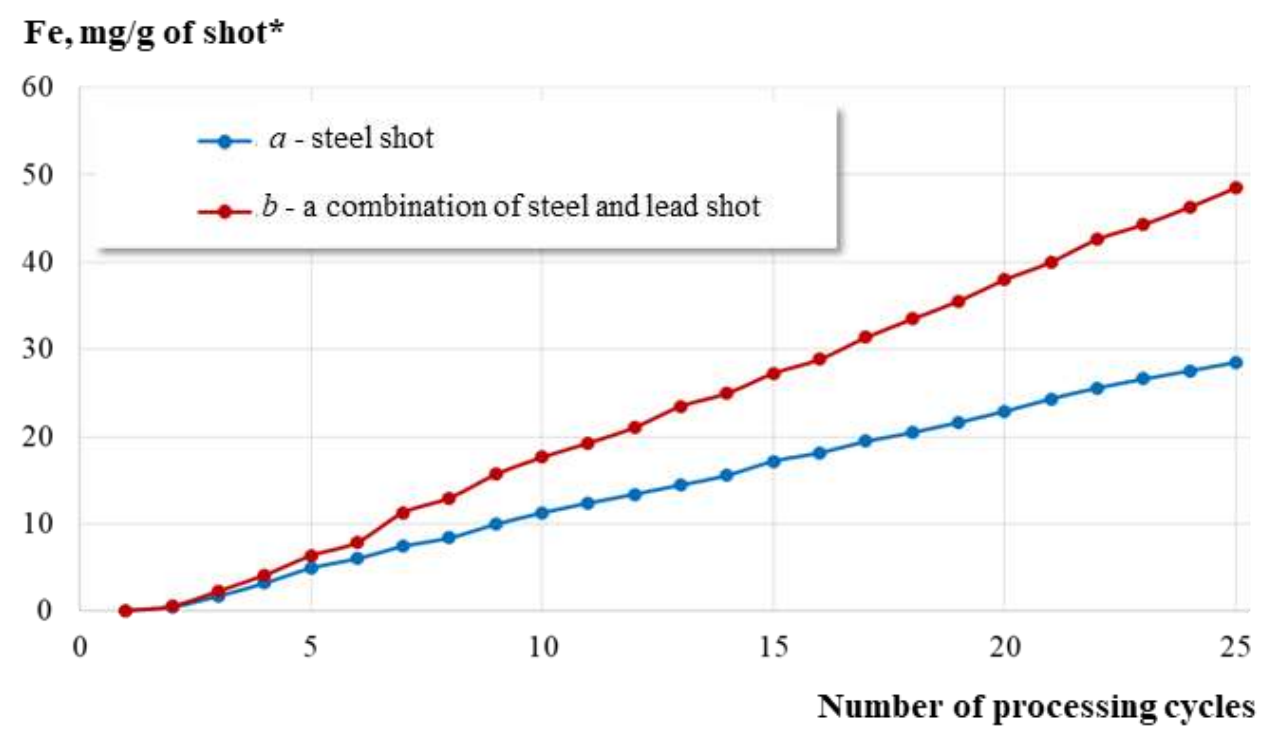

*the assessment is performed according to a cumulative system

Fig. 1. Steel shot dissolution in atmospheric precipitation

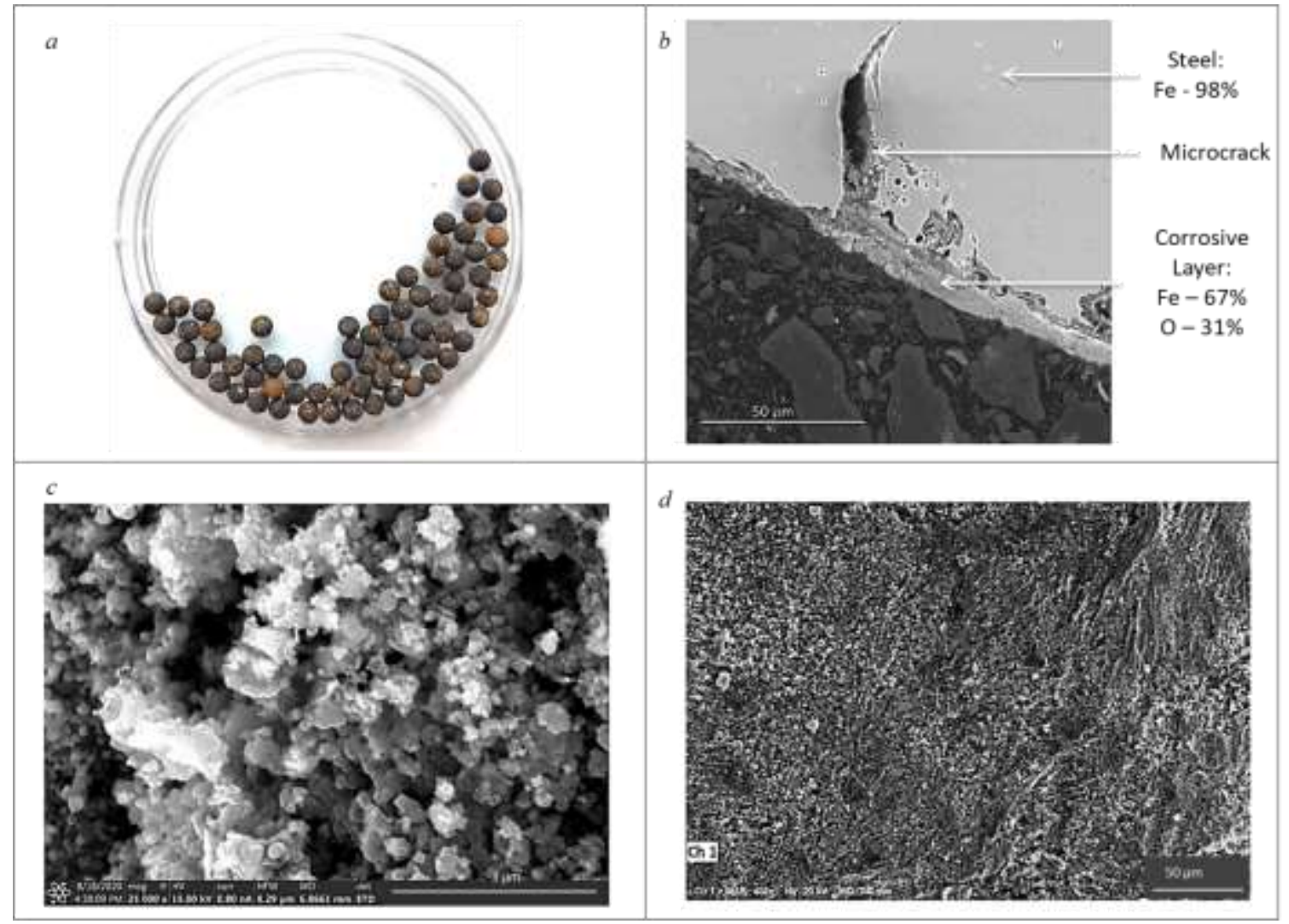

Fig. 2. The general appearance of steel shot after interaction with atmospheric precipitation, and the results of SEM (steel shot exposed alone):

$\mathrm{a}-$ shot with visible secondary changes, $\mathrm{b}-\mathrm{a}$ layer of corrosion products and micro-cracks on shot filled with corrosion products, $\mathrm{c}$ - the structure of corrosion products (iron oxides), $\mathrm{d}-$ the shot surface with areas where the corrosion product crust peels off the surface. 
The steel shot surface includes areas with a peeled-off corrosion product coating (Fig. 2, d) which indicates poor adhesion of iron oxide to the shot surface. The corrosion process is dynamic and is constantly involving new metal volumes. Therefore, in this solution, the steel shot can be almost completely transformed into its oxidized state under the impact of the environment.

In the presence of metallic lead, the process of steel shot dissolution is the same, but its rate increases significantly (Fig. 1, b). Over the experiment period, the total iron loss was $4.7 \%$ of the initial mass, which is 1.7 times more than for steel shot exposed alone. The average rate of steel shot dissolution when exposed together with lead shot is $0.05 \%$ per day. Steel shot transformation determines the prevalence of suspended iron forms since the early experiment stage (Table 1).

The formation of corrosion crusts is visible on both steel shot and lead shot (Fig. 3, a). According to the SEM data, a corrosion product coating with a thickness of 5-50 $\mu \mathrm{m}$ forms on the surface of steel shot, in areas with surface micro-cracks - with a thickness of up to 100 forms and more (Fig. 3, b). Morphologically, the coating is a layer of fine crystalline which consists of iron oxides and lead-based deposits (Fig. 3, c) covering parts of the steel shot surface. Lead is observed inside the coating (Fig. 3, d), which indicates that $\mathrm{Pb}$ is captured from the aquatic solution during the formation of the iron oxide coating on the steel surface. These particles may act as local corrosion catalysts as evidenced by an increased coating thickness compared to a sample of steel shot exposed alone.

It should be noted that the presence of steel and lead shot simultaneously is a critical factor for lead shot transformation - this process accelerates significantly in the presence of steel shot, thus posing additional risks of lead contamination. The lead loss throughout the experiment was $0.11 \%$ for lead shot exposed alone and $0.91 \%$ (eight times higher) for lead shot exposed together with steel shot (Fig. 4). The obtained results are consistent with the weighing of shot before and after the experiment (Table 2).

In general, lead shot transformation is considerably slower than steel shot -25 times and 5 times slower when exposed alone and together with steel shot, respectively. When lead shot interacts with atmospheric precipitation without steel, it begins to oxidize, and the oxide coating dissolves partially (cycles of processing 1-7), which determines the release of lead into the corresponding interaction solutions where it is mainly present in the dissolved form (the content of dissolved forms $-0.6-1.5 \mathrm{mg} / \mathrm{l}$, the content of suspended forms $-0.1-0.3 \mathrm{mg} / \mathrm{l})$. The encapsulation of lead shot is accompanied by the formation of separate sediment particles from lead oxide compounds (cycles of processing 8-16, Fig. 5) which increases the content of suspended lead forms significantly $(1.6-3.8 \mathrm{mg} / \mathrm{l})$. Afterwards, the content of suspended lead forms decreases (to $0.5-1.2 \mathrm{mg} / \mathrm{l}$ ), and their presence is determined by the partial dissolution of the oxide encapsulating coating and the re-deposition of lead ions in a nearly neutral medium. 


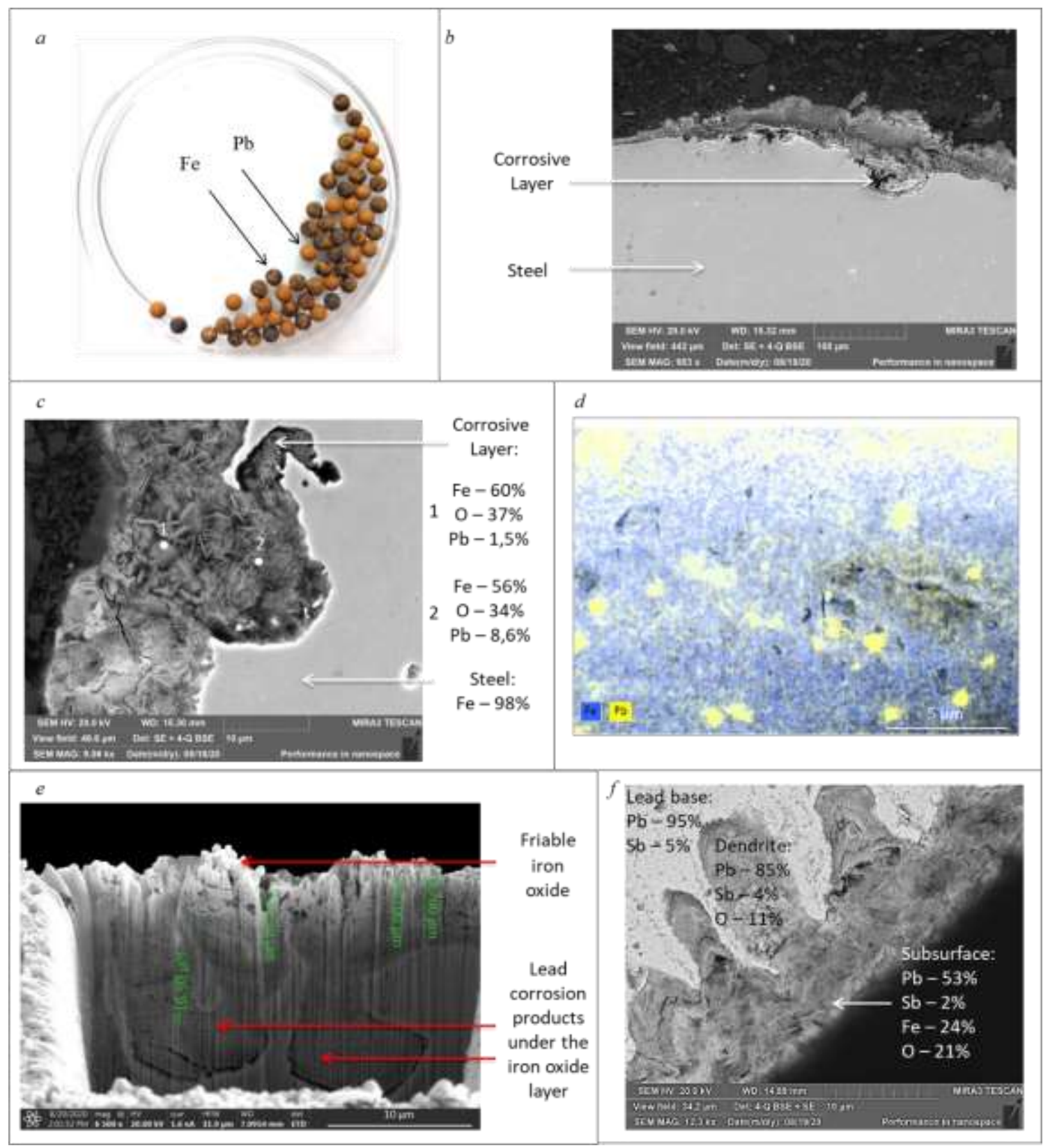

Fig. 3. The general appearance of steel and lead shot after interaction with atmospheric precipitation, and the results of SEM (steel and lead shot exposed together):

$\mathrm{a}$ - shot with visible secondary changes, $\mathrm{b}-\mathrm{a}$ layer of corrosion products and micro-cracks on shot filled with corrosion products, $\mathrm{c}-$ the morphology of steel shot corrosion products, $\mathrm{d}-$ lead particles inside the iron oxide coating on steel shot (a sectional view of the coating), $\mathrm{e}$ - the structure of the corrosion crust on lead shot, $\mathrm{f}$ - the degree of lead shot surface corrosion. 


\section{$\mathrm{Pb}, \mathrm{mg} / \mathrm{g}$ of shot}

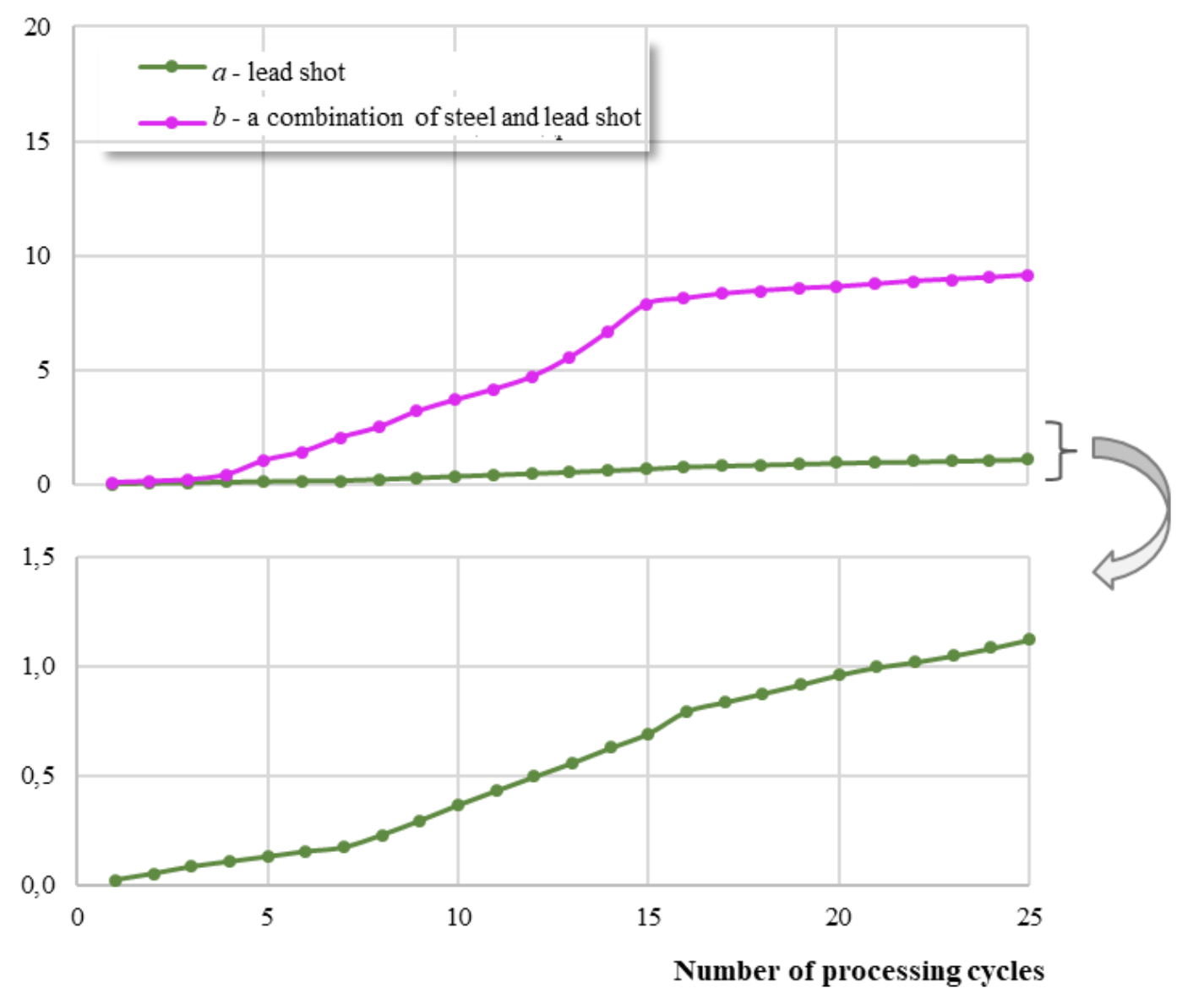

*the assessment is performed according to a cumulative system

Fig. 4. Lead shot dissolution in atmospheric precipitation

First 5-7 cycles

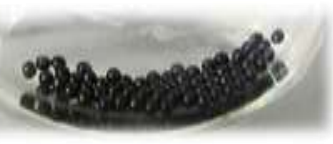

From 8th to 16th cycles

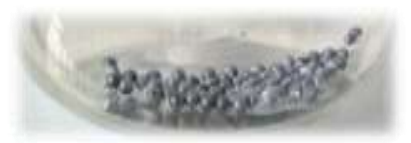

The 25 th cycle

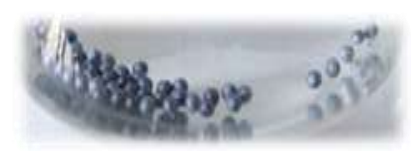

Gradual metal surface oxidation, formation of separate sediment particles from lead oxide compounds, encapsulation of the shot surface by a coating of dove-grey lead oxide compounds

Fig. 5. Gradual metal surface oxidation and encapsulation of lead shot exposed alone in atmospheric precipitation 
In the presence of steel shot, lead ions are captured from the solution by iron oxides and are co-deposited together with iron, intensifying the lead shot deterioration. As a result, lead is mainly suspended form in the interaction solutions (Table 1). Lead content varies in a wide range depending on the stage of lead shot surface encapsulation (from $1.2 \mathrm{mg} / \mathrm{l}$ to $30 \mathrm{mg} / \mathrm{l}$ ). The surface encapsulation is a gradual process; after 15 cycles of processing, which correspond to 60 days of interaction (Fig. 4, b), the release of lead ions into the solution and their subsequent co-deposition with iron hydroxides decreases significantly. The SEM results show that, in the presence of steel, a corrosion layer is formed on the lead shot surface which has a thickness of 5-25 $\mu \mathrm{m}$ and a complicated structure: there is a friable iron-containing coating with a thickness of up to $10-15 \mu \mathrm{m}$ on the upper surface, and a layer of lead oxygen compounds beneath (Fig. 3, $e$ ). There is no iron inside the lead compound layer. Lead shot surface mostly deteriorates on the primary dendrites, with the space between dendrites less prone to corrosion (Fig. 3, $f$ ).

Additional encapsulation of lead shot with a screening layer of iron oxide, the sorption of lead ions on the surface of steel shot corrosion layer, and the co-deposition of lead with iron oxides, which are formed due to steel shot dissolution, partially compensate the risks associated with an increased rate of lead shot transformation. Due to these factors, the interaction solutions are mainly characterized by a low content of dissolved lead forms (ions and complexes) between 0.04 and $0.38 \mathrm{mg} / \mathrm{l}$, on average $-0.19 \mathrm{mg} / \mathrm{l}$.

\section{Factor - Acid precipitation}

Interaction between steel shot and acid precipitation (the same as atmospheric precipitation) causes alkalization of solutions, partly reducing the initial acidity. The $\mathrm{pH}$ of interaction solutions varied between 5.3 and 6.3 , and the specific electrical conductivity remained at $11-18 \mu \mathrm{S} / \mathrm{cm}$ (except for the $1^{\text {st }}$ processing cycle, $\mathrm{pH}$ of 6.8 and $\sigma$ of $67 \mu \mathrm{S} / \mathrm{cm}$ ).

The $\mathrm{pH}$ of interaction solutions is higher than the $\mathrm{pH}$ of early ferric hydroxide deposition ( $\mathrm{pH}=2.5-4.5$ at $25^{\circ} \mathrm{C}$ for dissolved solutions), which results in the total iron content comparable to the scenario with atmospheric precipitation, and the prevalence of the suspended iron form (Table 1). However, the dissolved iron form content is significantly higher than in the case of atmospheric precipitation with $\mathrm{pH} 6(0.4-0.8 \mathrm{mg} / \mathrm{l})$. In the presence of lead shot, the physical and chemical characteristics of the medium are similar $(\mathrm{pH}=5.5-6.5$, and $\sigma=10-16$ $\mu \mathrm{S} / \mathrm{cm}$, apart from the first cycle of processing with $30 \mu \mathrm{S} / \mathrm{cm}$ ), and dissolved iron forms are absent since the early experiment phase (on average $<0.05 \mathrm{mg} / \mathrm{l}$, with a maximum value of 0.11 $\mathrm{mg} / \mathrm{l})$.

The curves of steel shot dissolution under the impact of environmental factors (Fig. 6, $a$, $b$ ) replicate the distribution obtained for the interaction with atmospheric precipitation (Fig. 1, $a, b$ ). The similarity between the curves is observed both in the case of steel shot exposed alone and together with lead, with lead increasing the deterioration rate of steel shot 1.7 times. Over the duration of the experiment, the iron loss was $2.9 \%$ and $4.9 \%$ of the initial shot mass (for steel shot exposed alone and in combination with lead, respectively). In general, the obtained assessment of iron loss based on iron concentration in interaction solutions correlates to the evaluation of shot mass loss using the weight method (Table 2).

In general, the appearance of steel shot after interaction with acid precipitation and the nature of its deterioration correspond to the interaction with atmospheric precipitation (Fig. 7, 8). Without lead shot (Fig. 7, a), the main product of steel shot corrosion is the friable iron 
oxides in the form of round-shaped submicron particles (Fig. 7, $c$ ), similar to the oxide coating on samples interacting with atmospheric precipitation with atmospheric. The local thickness of the corrosion layer is $10-50 \mu \mathrm{m}$, in areas with surface micro-cracks - up to $100 \mu \mathrm{m}$ and more (Fig. 7, $b$ ). As in the case of atmospheric precipitation, there are areas with a peeled-off coating (Fig. 7, d). It means that steel oxidation is accompanied by the dynamic corrosive transformation of the basis metal. It can be assumed that under the impact of acid precipitation steel shot would corrode until the steel is completely transformed into iron oxide (III).

When steel and lead shot are exposed together (Fig. 8, a), the oxidation of metallic lead under environmental factors results in the formation of metal ions in the solution. As in the case of atmospheric precipitation, these metal ions are sorbed by the corrosive layer of steel, while iron oxides form a screening layer on the lead shot surface. According to the SEM data, the thickness of a corrosion product on steel shot is $20-50 \mu \mathrm{m}$, in areas with surface micro-cracks - up to $100 \mu \mathrm{m}$ and more (Fig. 8, $b$ ). The main product of steel shot corrosion in the presence of lead is a dense oxide layer of fine crystalline (Fig. 8,c) covered with more friable iron oxides on top (Fig. 8, d). Significant concentrations of lead (3-5\%) is observed on the shot surface, which indicates that it is deposited from the solution as a result of the steel corrosion process.

At the same time, an iron oxide layer (Fig. 8,e) with a local thickness of 7-10 $\mu \mathrm{m}$ is formed on the surface of lead shot (an alloy of $\mathrm{Pb}$ and $\mathrm{Sb}$ ) in the presence of steel. The chemical deterioration of lead shot reaches 10-30 $\mu \mathrm{m}$ inwards from the shot surface (Fig. 8, $f$ ).

As the interaction solutions of lead shot with acid precipitation have a lower $\mathrm{pH}$ than in the case of atmospheric precipitation (on average - 5.5 and 6.0 for lead shot exposed alone and in combination with steel shot, respectively) and is comparable to the $\mathrm{pH}$ of early deposition of lead hydroxide ( $\mathrm{pH}=6.0$ at $25^{\circ} \mathrm{C}$ for dissolved solutions), the rate of lead shot dissolution is higher.

When lead shot was exposed alone, the total content of lead in interaction solutions varied between 16-29 mg/l in the solutions of cycles of processing $1-3$ to $5.0-7.9 \mathrm{mg} / \mathrm{l}$ in the subsequent period. The high lead content during the early experiment phase and the prevalence of its suspended form during that time (Table 1) are determined by intensive lead shot deterioration with the formation of flocculent deposits of lead oxygen compounds (Fig. 9, $a$ ). Under the impact of acid precipitation, the encapsulation process continued for 15-20 days (45 cycles of processing, Fig. 9, b); afterwards, the content of lead in interaction solutions is determined by the release of lead ions due to the dissolution of the shot oxide layer (Table 1). Throughout the experiment period, lead loss as the result of shot deterioration was $0.41 \%$ (Fig. $10, a)$.

In the presence of steel, lead shot corrodes mainly with the formation of suspended forms, their share reaching the maximum value during the period of the most active deterioration (between the 4th and the 11th cycle of processing with acid precipitation, Table 1). During that period, the total content of lead in the solution was $19-45 \mathrm{mg} / \mathrm{l}$, later decreasing to $6.3 \mathrm{mg} / \mathrm{l}$ on average. Lead loss as the result of shot deterioration was $1.5 \%$ (Fig. 10, b). Therefore, the presence of steel increases the lead shot corrosion rate 3.7 times, however, the sorption and co-deposition of lead with iron oxides results in a lower content of lead ions and complexes $(0.4-2.5 \mathrm{mg} / \mathrm{l}$, on average $-1.0 \mathrm{mg} / \mathrm{l})$. 


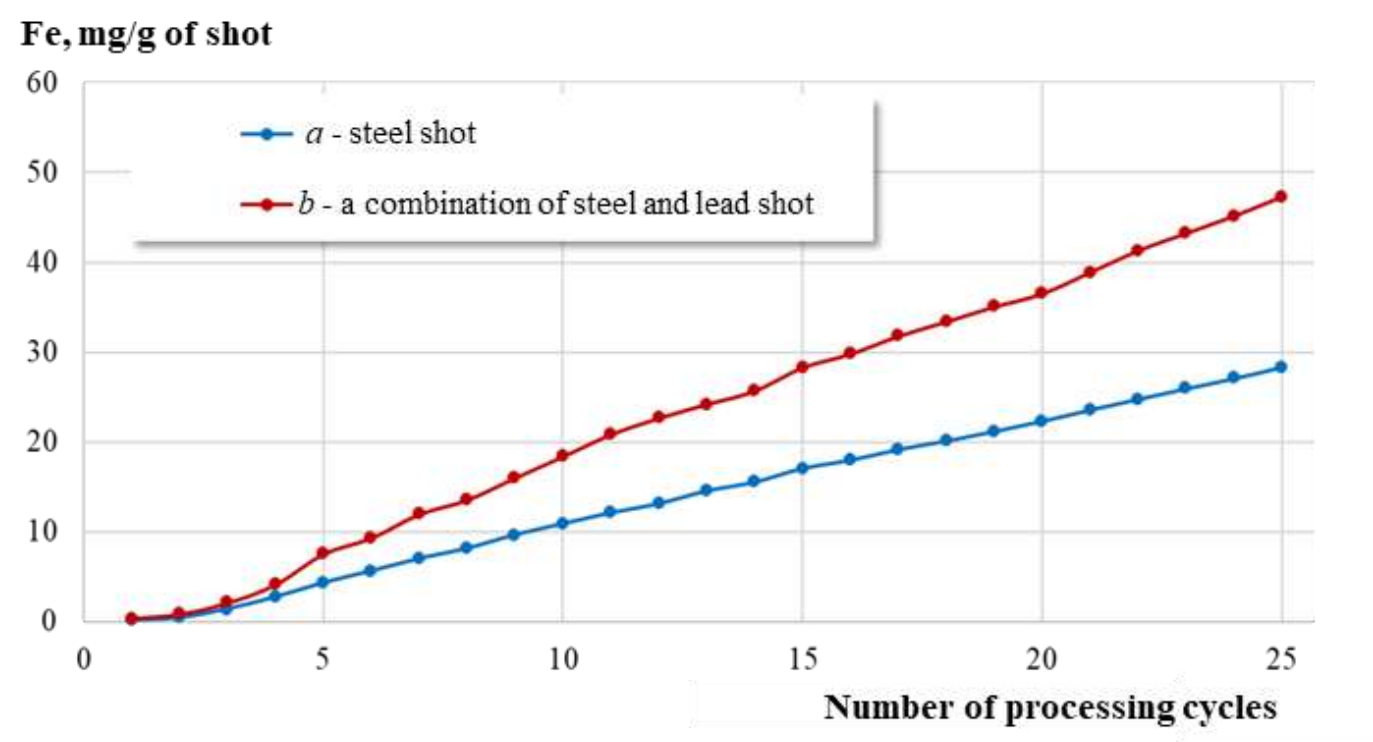

*the assessment is performed according to a cumulative system

Fig. 6. Steel shot dissolution in acid precipitation

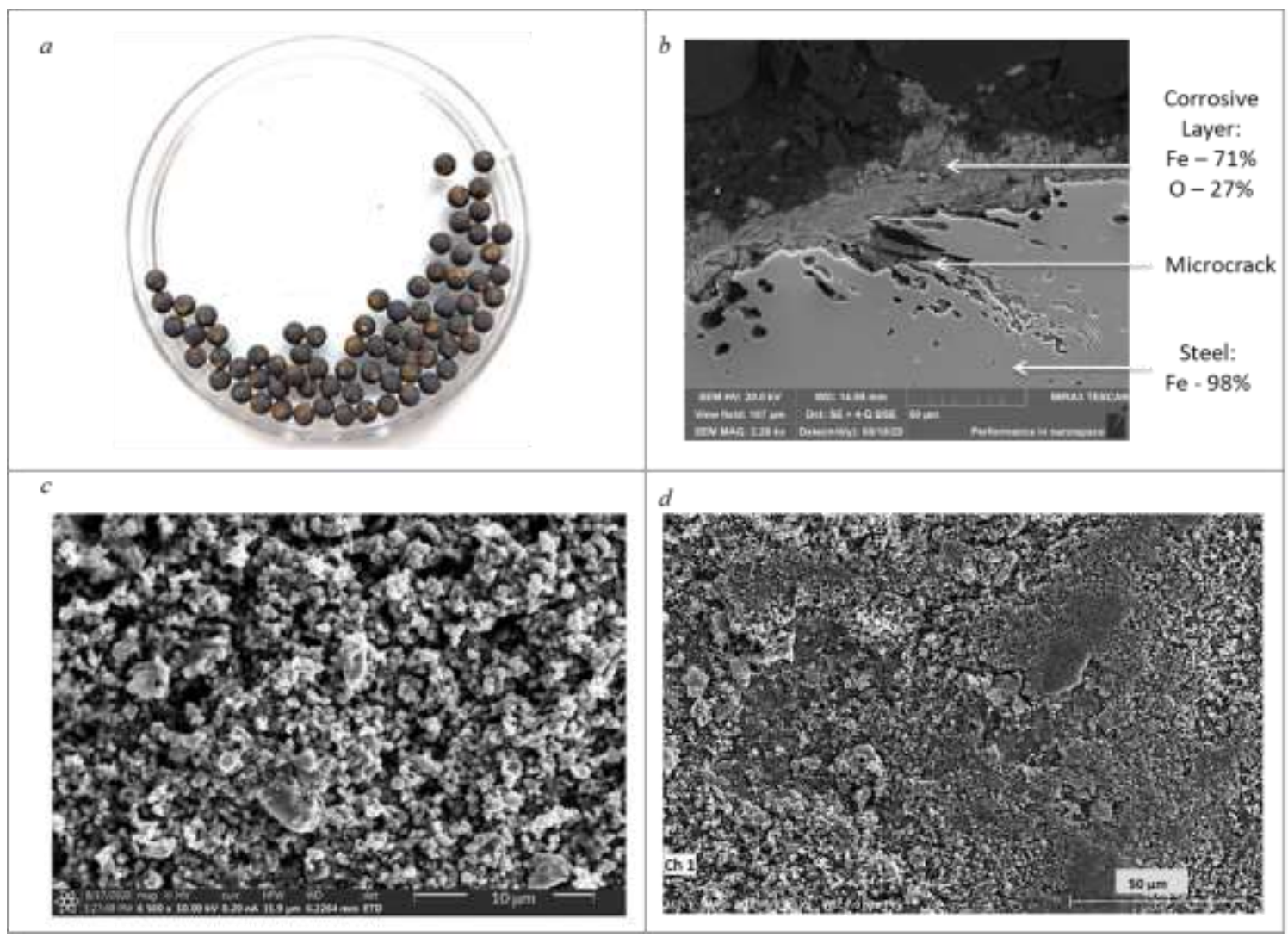

Fig. 7. The general appearance of steel shot after interaction with atmospheric acid precipitation, and the results of SEM (steel shot exposed alone):

$\mathrm{a}$ - shot with visible secondary changes, $\mathrm{b}-\mathrm{a}$ layer of corrosion products and micro-cracks on shot filled with corrosion products, $c$ - the structure of corrosion products (iron oxides), $d$ - the shot surface with areas where the corrosion product crust peels off the surface. 


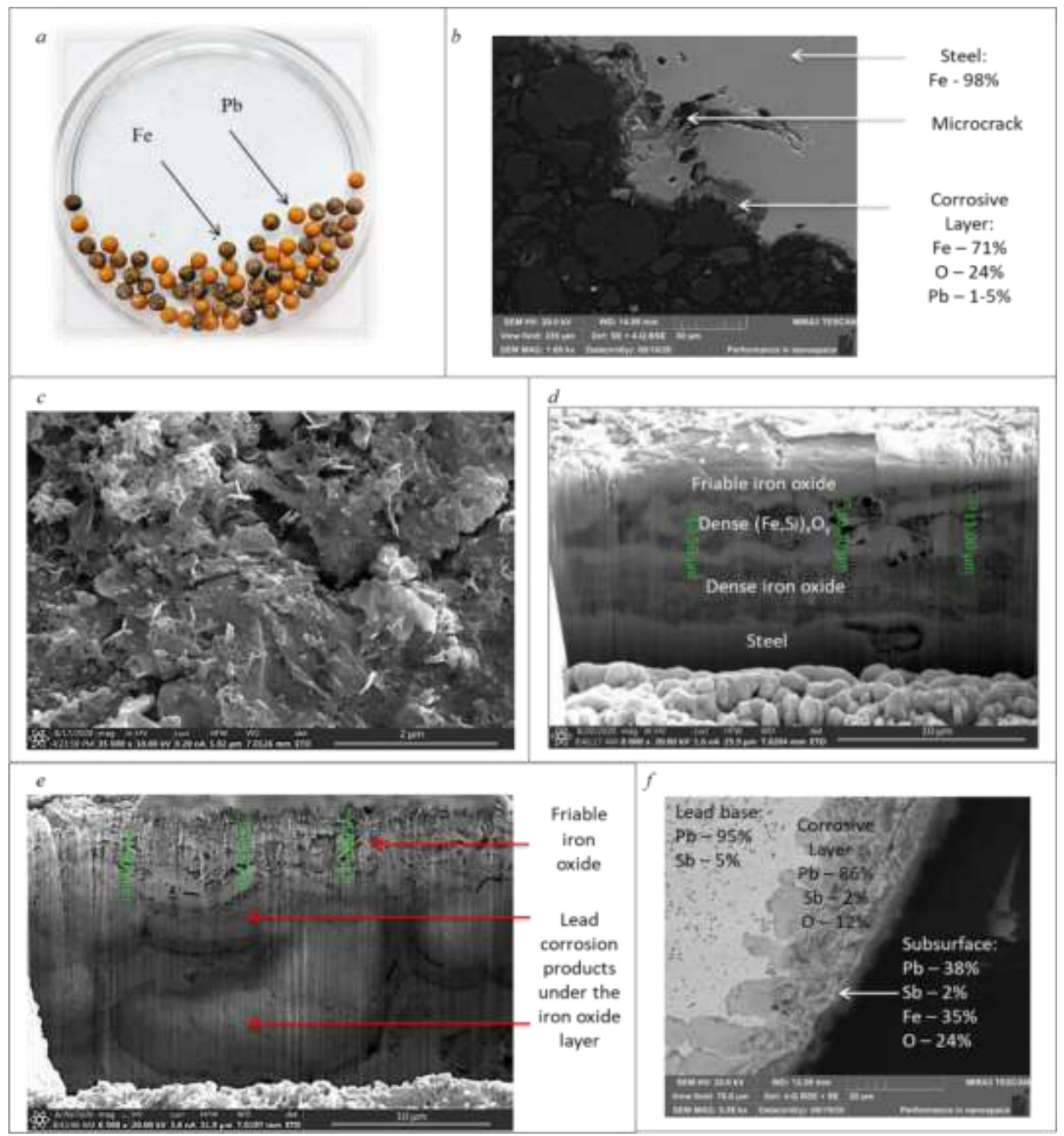

Fig. 8. The general appearance of steel and lead shot after interaction with acid precipitation, and the results of SEM (steel and lead shot exposed together):

$\mathrm{a}$ - shot with visible secondary changes, $\mathrm{b}$ - a layer of corrosion products and micro-cracks on shot filled with corrosion products, $\mathrm{c}$ - the morphology of steel shot corrosion products, $\mathrm{d}-$ the structure of the corrosion crust on steel shot, e - the structure of the corrosion crust on lead shot, $\mathrm{f}$ - the degree of lead shot surface corrosion.

First 3 cycles

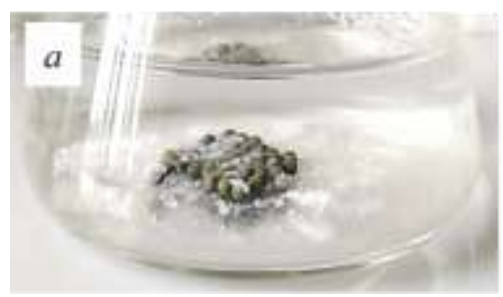

After the 5th cycle

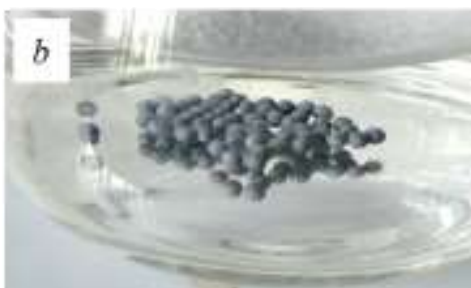

Fig. 9. The metal surface oxidation and encapsulation of lead shot exposed alone in acid precipitation: a - intense oxidation of metal surface with formation of white flocculent sediment (lead hydroxides and sulfates), $b$ - encapsulation of the shot surface by a coating of dove-grey lead oxide compounds. 

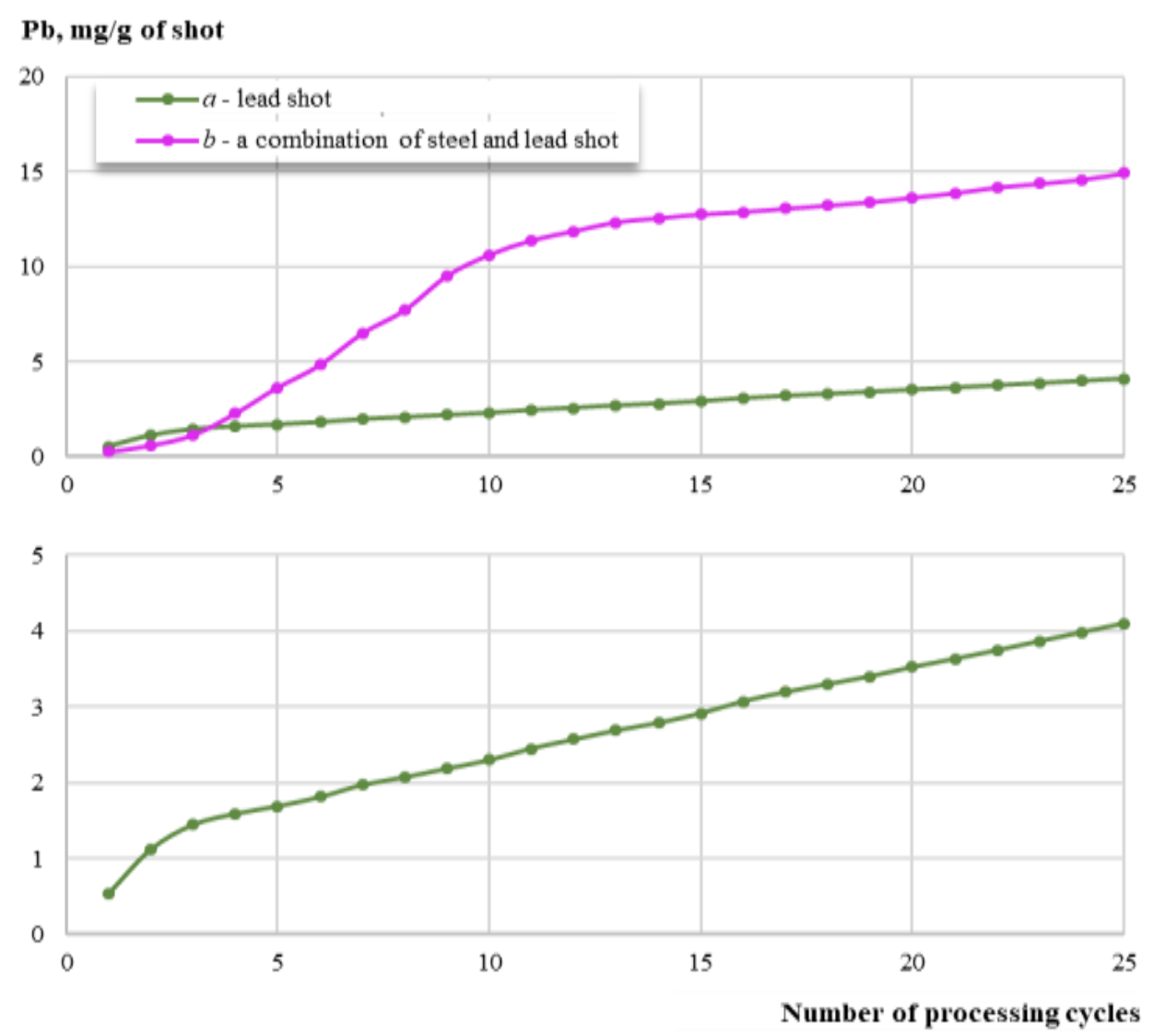

*the assessment is performed according to a cumulative system

Fig. 10. Lead shot dissolution in acid precipitation

\section{Factor - Soil solutions}

Soil solutions are the most aggressive environmental factor with a high buffer capacity: after interaction with shot, they retain the initial physical and chemical characteristics (in all the scenarios, except for the 1 st and 2 nd cycles of processing).

Steel shot transformation relatively uniformly under the impact of soil solutions (Fig. 11, $\mathrm{a}, \mathrm{b})$. In the absence of metallic lead, the average total content of iron in interaction solutions ( $5 \mathrm{~g}$ of shot, $100 \mathrm{ml})$ is $498 \mathrm{mg} / \mathrm{l}$, when exposed together with lead shot $(2.5 \mathrm{~g}$ of each type of shot, $100 \mathrm{ml}$ ) - $321 \mathrm{mg} / \mathrm{l}$. Iron is mainly present in the dissolved form (as acetate complexes). The share of dissolved forms during the early interaction phase is $97-99 \%$ of the total metal content. Later, suspended iron forms appear, causing the release of iron ions and complexes from the solution; the average share of suspended forms reaches $33 \%$ and $20 \%$ of the total iron content for steel shot exposed alone and in combination with lead shot, respectively (Table 1).

Considering the high iron content and the prevalence of its suspended forms for steel shot exposed alone, it may be assumed that interaction solutions will be oversaturated with this element, provided that lead does not interfere with the complex formation process and that there is a lower ratio of steel shot to the solution. The iron loss throughout the experiment was $25 \%$ of the initial mass for steel shot exposed alone (Fig. 11, a), and 32\% for steel shot exposed together with lead shot (Fig. 11, b), which corresponds to $0.25 \%$ and $0.32 \%$ per day, respectively. The calculations of the mass loss of steel shot (based on the iron content in interaction solutions) are confirmed by the results of the weight method (Table 2). 
A visual examination of steel shot after interaction with model soil solutions (Fig. 12, $a$; Fig. 13,a) showed irregularities and cavities on its surface, indicating local corrosion of iron.

According to the SEM data, a corrosion layer with a thickness of 5-10 $\mu \mathrm{m}$ forms on the surface of steel shot, in areas with surface micro-cracks - up to $50 \mu \mathrm{m}$ and more (Fig. 12, $b$ ). The relative thinness of the corrosion coating under the impact of an aggressive environmental factor is determined by the continuous removal of corrosion products from the steel shot surface into the interaction solution. The main corrosion product is the porous iron oxide coating (Fig. 12,c); in profile, it consists of two layers: an outside dense layer of iron corrosion products with a higher oxygen concentration, and an intermediary layer of iron oxides underneath (Fig. 12, $d$ ). Due to the difference in the continuity of the upper and lower layers, the surface of steel shot has a considerable relief formed under the impact of a corrosive medium (Fig. 12, b).

In the presence of a lead shot, a coating with a thickness of 5-20 $\mu \mathrm{m}$ forms on the surface, in areas with surface micro-cracks - with a thickness of up to $50 \mu \mathrm{m}$ and more. There is also local corrosion (Fig. 13, b). The coating has a lamellar and fine-crystalline morphology and consists of iron oxides and lead-based deposits (Fig. 13,c). The latter form interlayers inside the corrosion profile which indicates that lead is captured from the interaction solution during the formation of the iron oxide coating on the steel surface (Fig. 13,d).

In the presence of steel, an iron oxide coating with a weblike morphology forms on the lead shot surface. There are separate areas of flocculent iron oxide deposits (Fig. 13, e). Iron oxides are not visible (Fig. 13,a), which is only present in small fragments. The local thickness of the corrosion layer on the lead shot surface is $3-8 \mu \mathrm{m}$. The lead oxide layer is covered with organic acid salts (Fig. 13, f).

The chemical transformation of the lead oxide coating on the lead shot surface results in the release of metal into the interaction solutions. When the lead shot is exposed alone, and iron does not interfere, the lead content in the interaction solutions varies between 193 and $488 \mathrm{mg} / \mathrm{l}$ (on average - $280 \mathrm{mg} / \mathrm{l}$ ) with the entire metal present in dissolved forms (Table 1) as acetate complexes. Over the duration of the experiment, the total lead loss as a result of lead shot corrosion was $14 \%$, which corresponds to the average rate of $0.14 \%$ per day (Fig. 14, a).

In the presence of steel shot, the lead content in interaction solutions was significantly lower - 9.4-26 mg/l (on average - $14.1 \mathrm{mg} / \mathrm{l}$ ). This is because iron, as a more active metal, interferes with the process and forms more stable acetate complexes than lead (Log K 7.57 and 4.08 for $\mathrm{Fe}[$ Acetate 2 and $\mathrm{Pb}$ [Acetate]2, respectively (NIST Critically Selected Stability Constants of Metal Complexes Database). As a result, the share of suspended lead forms is slightly higher (about $5 \%$ of the total lead content, Table 1) and is determined by the codeposition of lead ions with iron oxide compounds which form as a result of steel corrosion. The calculated mass loss of lead shot (based on the lead content in interaction solutions) was $1.4 \%(0.014 \%$ per day) which is confirmed by the weight method results (Table 2$)$. 


\section{$\mathrm{Fe}, \mathrm{mg} / \mathrm{g}$ of shot}

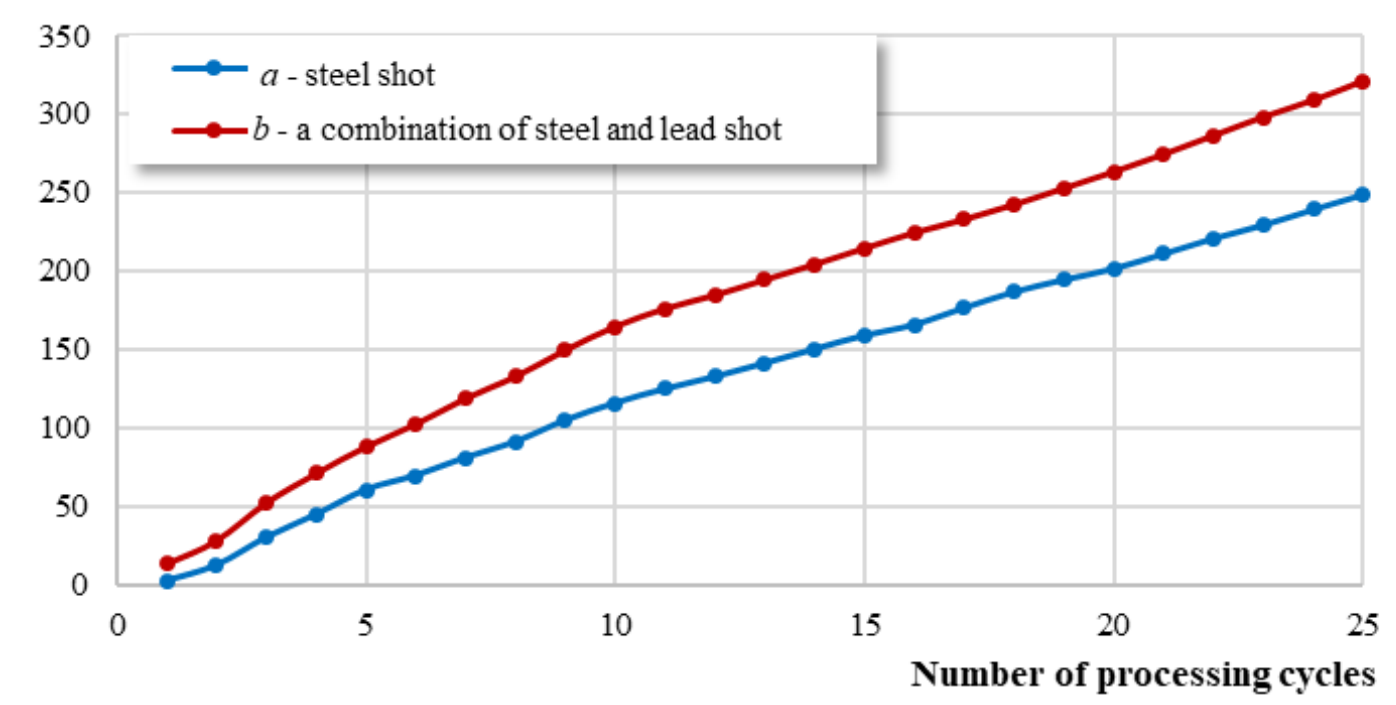

*the assessment is performed according to a cumulative system

Fig. 11. Steel shot dissolution in soil solutions with organic acids

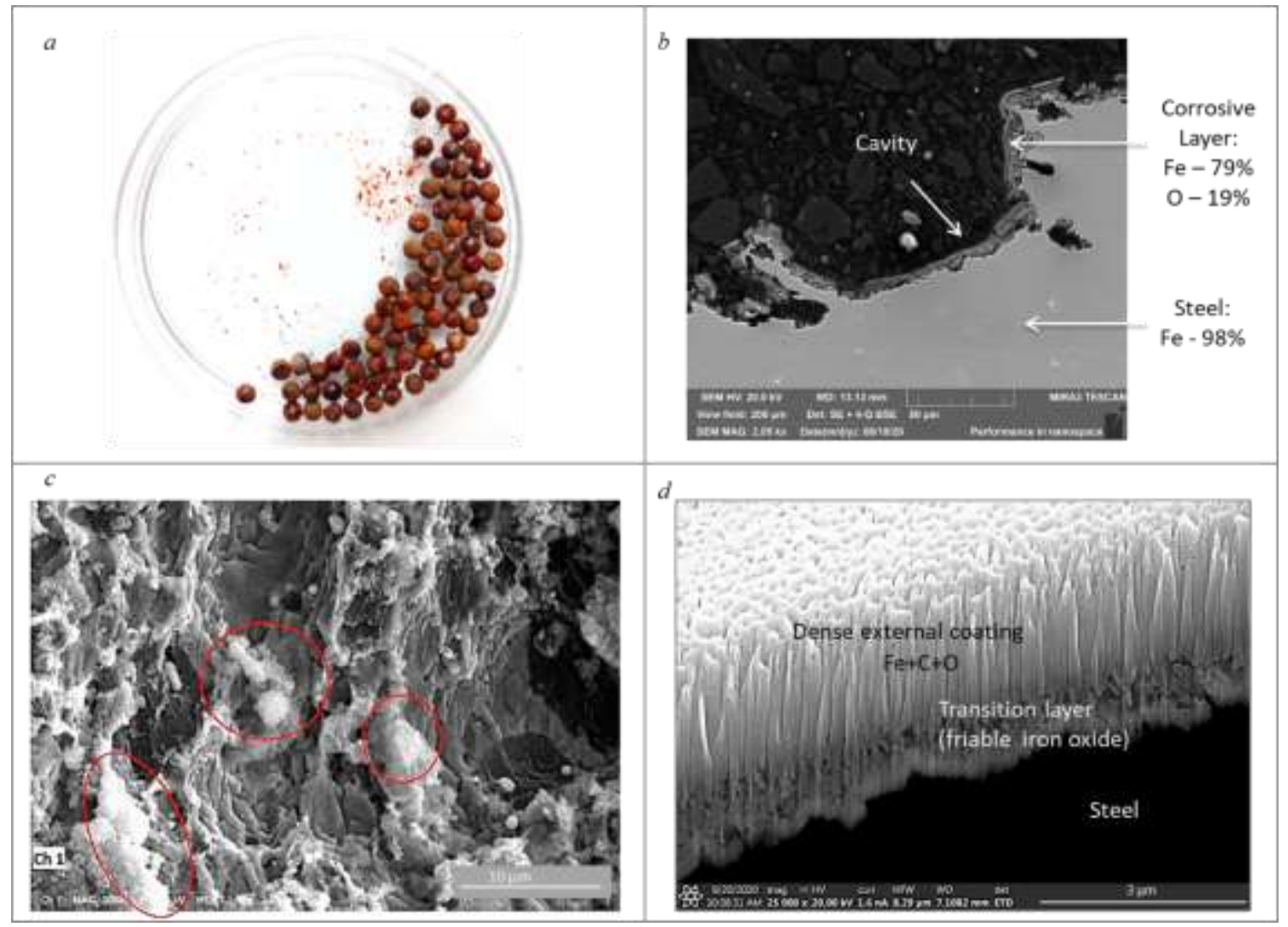

Fig. 12. The general appearance of steel shot after interaction with soil solutions, and the results of SEM (steel shot exposed alone):

$\mathrm{a}$ - shot with visible secondary changes, $\mathrm{b}$ - the composition and thickness of a corrosion crust on the shot surface, $\mathrm{c}$ - a porous iron oxide coating with flocs with a higher concentration of $\mathrm{C}$ and $\mathrm{O}$ deposited on its surface (highlighted by red ellipses), $\mathrm{d}$ - the two-layer structure of the corrosion coating (profile). 


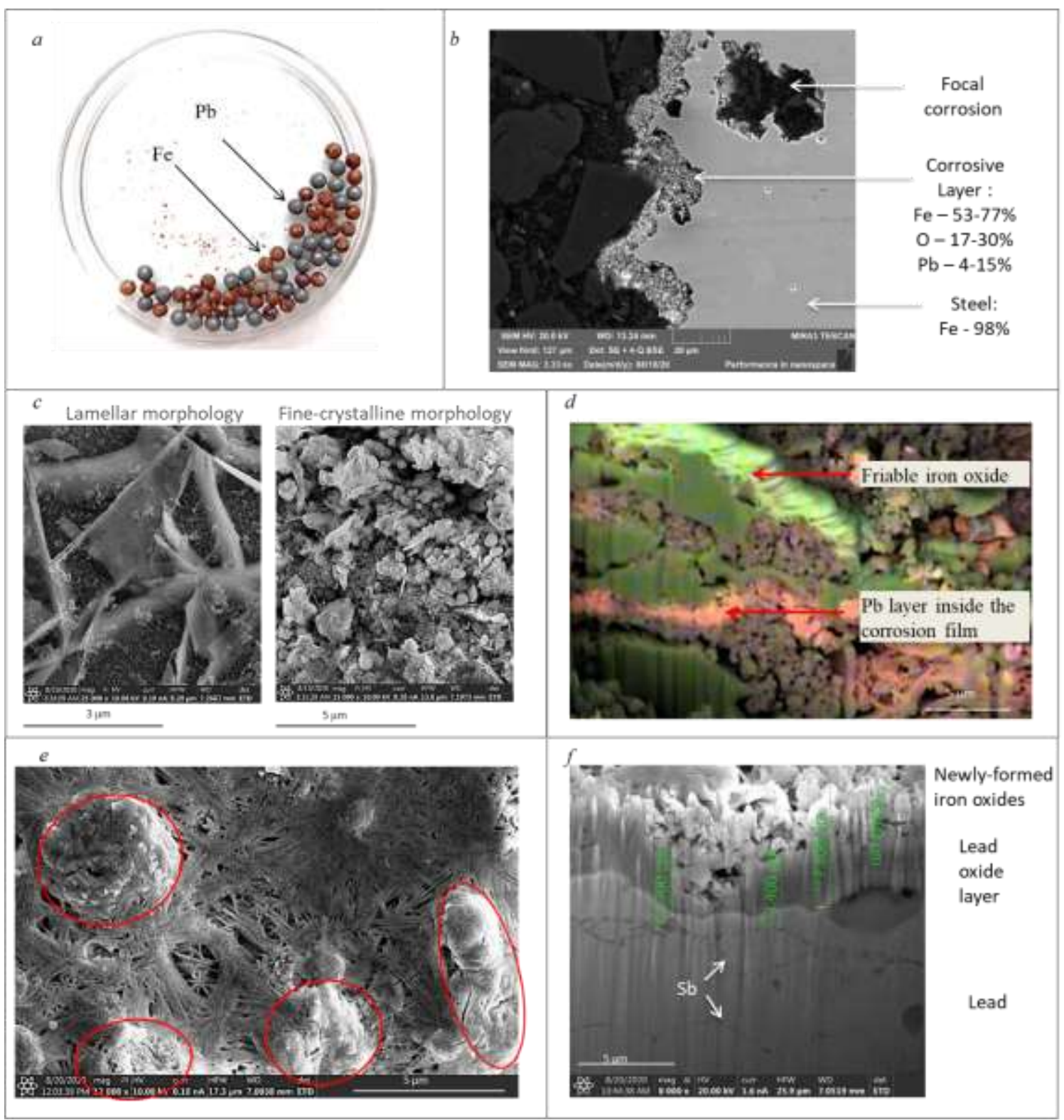

Fig. 13. The general appearance of steel and lead shot after interaction with model soil water, and the results of SEM (steel and lead shot exposed together): $\mathrm{a}$ - shot with visible secondary changes, $\mathrm{b}$ - the composition and thickness of a corrosion crust on steel shot, $\mathrm{c}$ - the lamellar and fine-crystalline morphology of corrosion products, $\mathrm{d}$ - the structure of the corrosion crust on steel shot (in profile), e iron oxide coating with a weblike morphology on the lead shot surface with separate areas of flocculent iron oxide deposits (highlighted by red ellipses), $\mathrm{f}$ - the structure of the corrosion crust on lead shot. 


\section{$\mathrm{Pb}, \mathrm{mg} / \mathrm{g}$ of shot}
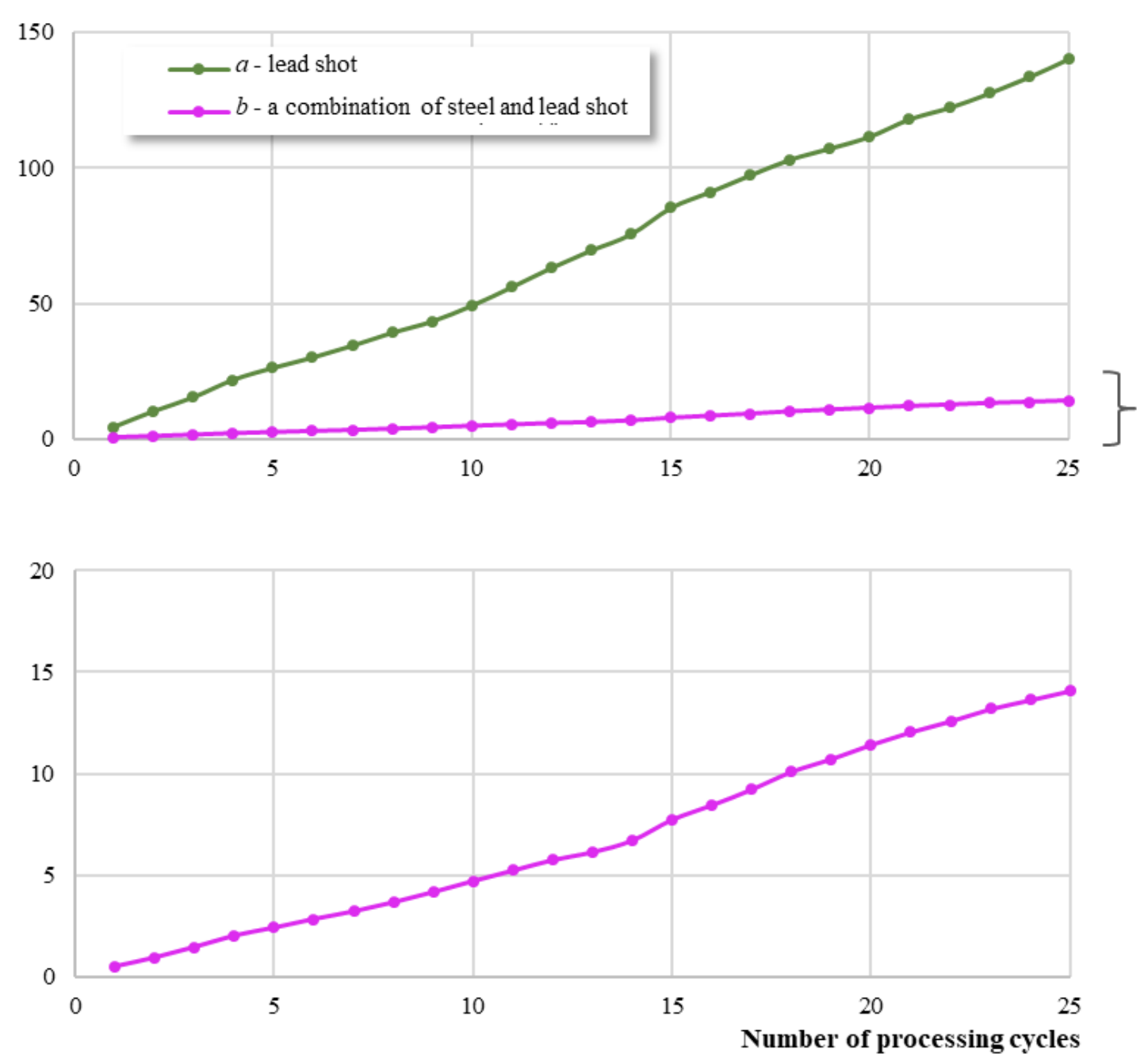

*the assessment is performed according to a cumulative system

Fig. 14. Lead shot dissolution in soil solutions with organic acids

\section{COMPARATIVE ASSESSMENT OF STEEL SHOT AND LEAD SHOT TRANSFORMATION UNDER THE ENVIRONMENTAL FACTORS}

The comparison of the experiment results allowed to produce a comparative assessment of steel and lead shot transformation under the impact of extreme environmental factors (Table 3 ). The period of complete shot destruction for various use scenarios was calculated by extrapolating assessments of average shot transformation rate at specified experiment parameters.

Under constant atmospheric precipitation of various acidity, steel shot destruction uniformly. The reduction of hydrogen ions during the oxidation of steel shot determines the alkalization of interaction solutions where iron is present in suspended forms. The estimated period of complete steel shot destruction is about ten years, while in the presence of metallic lead, it is decreased to 5.5-6 years. 
Table 3. Comparative assessment of shot destruction under the environmental factors in the extreme conditions of permanent humidification

\begin{tabular}{|c|c|c|c|c|}
\hline Shot forms & $\begin{array}{l}\text { Environmental } \\
\text { factor }\end{array}$ & $\begin{array}{c}\text { Average shot } \\
\text { destruction rate, } \% \text { of } \\
\text { initial mass per day }\end{array}$ & $\begin{array}{l}\text { Estimated period of } \\
\text { complete shot } \\
\text { deterioration, years }\end{array}$ & $\begin{array}{c}\text { The primary form of metal } \\
\text { in interaction solutions, } \% \\
\text { of total content }\end{array}$ \\
\hline \multicolumn{5}{|c|}{ Steel shot } \\
\hline \multirow{3}{*}{ Exposed alone } & $\begin{array}{l}\text { Atmospheric } \\
\text { precipitation }\end{array}$ & 0.028 & 9.8 & Suspended $(>99.9)$ \\
\hline & Acid precipitation & 0.029 & 9.4 & Suspended (99) \\
\hline & Soil solutions & 0.25 & 1.1 & Dissolved (70) \\
\hline \multirow{3}{*}{$\begin{array}{l}\text { In combination } \\
\text { with lead shot }\end{array}$} & $\begin{array}{l}\text { Atmospheric } \\
\text { precipitation }\end{array}$ & 0.047 & 5.8 & Suspended (>99.9) \\
\hline & Acid precipitation & 0.049 & 5.6 & Suspended (>99.9) \\
\hline & Soil solutions & 0.32 & 0.9 & Dissolved (80) \\
\hline \multicolumn{5}{|c|}{ Lead shot } \\
\hline \multirow{3}{*}{ Exposed alone } & $\begin{array}{l}\text { Atmospheric } \\
\text { precipitation }\end{array}$ & 0.0011 & 249 & Dissolved (53) \\
\hline & Acid precipitation & 0.0041 & 67 & Dissolved (91) \\
\hline & Soil solutions & 0.14 & $2.0^{*}$ & Dissolved (99) \\
\hline \multirow{3}{*}{$\begin{array}{l}\text { In combination } \\
\text { with steel shot }\end{array}$} & $\begin{array}{l}\text { Atmospheric } \\
\text { precipitation }\end{array}$ & 0.0091 & 30 & Suspended (97) \\
\hline & Acid precipitation & 0.015 & 18 & Suspended (90) \\
\hline & Soil solutions & 0.014 & 20 & Dissolved (95) \\
\hline
\end{tabular}

* provided that iron does not interfere with the complex formation process, which is impossible in natural conditions

Interaction with soil solutions significantly accelerates steel shot destruction, with iron mostly present in interaction solutions in complexes with organic ligands. Under these conditions, the metal corrosion rate reaches its maximum values, and the steel shot may be fully destroyed for about one year (13 months for steel shot exposed alone and ten months for steel shot in the presence of metallic lead).

Lead shot is less sensitive to environmental factors due to the fast oxidation and passivation of the surface by oxidized compounds of lead. Under the impact of atmospheric precipitation, the lead shot destruction rate reaches the maximum and is a function of the acidity of precipitation. In the conditions of normal acidity precipitation, the period of complete lead shot deterioration is about 250 years. Acid precipitation intensifies the oxidation and dissolution of lead shot, thus shortening the deterioration period to 65-70 years. Lead is present mainly in dissolved forms (ions and compounds) that negatively affects the environment. The presence of steel shot intensifies the lead shot destruction (4-8 times) and shortens its complete assimilation by the environment to 20-30 years. The co-deposition of lead with iron oxides partially compensates for the risks associated with the presence of steel shot.

The maximum corrosion rate of lead shot is observed in the case of continuous contact with organic acids in soil solutions. The estimated dissolution period in the experimental conditions is 20 years for lead shot exposed together with steel shot and two years for lead shot exposed alone. The long period of lead shot transformation under the experimental conditions can be attributed to 1) iron acetate complexes have a definite competitive advantage when interacting with organic acid solutions; 2) lead ions are captured from the interaction solution during the formation of the iron oxide coating on the steel shot surface. 
The obtained results show that steel shot is characterized by a high rate of transformation under the environmental factors that is usually an order of magnitude higher than the transformation rate of lead under the same condition. The prevalence of the suspended iron form (excluding the interaction with organic acids) presents risks for environmental components such as soils and sediments and may be of hazard to the ambient air and natural waters in case of wind erosion and surface runoff from the catchment area. Furthermore, the presence of steel and lead shot together accelerates the corrosion of both metals, thus increasing the environmental risks.

\section{CONCLUSION}

It is necessary to exercise caution when making predictions about the environmental safety of replacing lead by steel in ammunition on shooting sites that were lead in soil, especially on sites that are not organized as shooting ranges, where lead has accumulated over decades due to hunting activities.

The steel shot presence with its high reactivity (especially in the presence of lead shot and its fragments) and the formation of suspended (flocculent) and mobile soluble iron compounds and complexes may result in uncontrollable growth of the pollution of environment:

- in temporary and permanent areas (zones) with a low load from shooting and no Risk Management Measures, including lead recycling, the primary hazard is the increase of soil pollution (since the possible increase in the depth of lead penetration) and groundwater with mobile lead species because the presence of steel shot increases lead shot transformation by 4 8 times and promotes its decapsulation (in the absence of steel shot, lead is low active and accumulates in the upper centimetres of the soil profile);

- in permanent areas with a high load from shooting, implementation of Risk Management Measures, including the catchment of surface runoff, with a high level of lead recycling (up to $90 \%$ ), the primary environmental hazard is the iron pollution of underground water due to the fact that the presence of lead increases steel shot transformation by $1.3-1.7$ times;

- steel shot and its corrosion products in the form of iron hydroxides are transported from shooting areas into water bodies and watercourses by surface runoff (provided that there are such water bodies and watercourses on the shooting areas, and no surface water controls are implemented); in such cases, iron toxicity is due to the mechanical damage and asphyxia of fish and other aquatic organisms caused by the deposition of flocculent iron hydroxides, and/or the decrease of oxygen content in water when oxygen is used to complete iron oxidation;

- infiltration of soluble iron compounds in the soil may lead to an increased iron content in the groundwater (water from natural sources consumed without any treatment) exceeding the Level of Concern (LOC). In various national regulations, the exposure LOC for iron content in drinking or surface water is strict enough $(0.1-0.3 \mathrm{mg} / \mathrm{l})$. Thus, if the load from shooting is high, LOC may be exceeded before any iron recycling measures can be implemented (where Risk Management Measures are applicable).

The information presented in this article proves that it is necessary to study the behaviour of steel shot in soils with/without lead, which will be the focus of further research by the article's authors. 


\section{REFERENCES}

Arnemo J.M., Andersen O., Stokke S.et al. (2016) Health and Environmental Risks from Leadbased Ammunition: Science Versus Socio-Politics. EcoHealth 13, 618-622. https://doi.org/10.1007/s10393-016-1177-x.

Bardack S., Dalgard C.L., Kalinich J.F., Kasper, C.E. (2014) Genotoxic Changes to Rodent Cells Exposed in Vitro to Tungsten, Nickel, Cobalt, and Iron. Int. J. Environ. Res. Public Health 11: 2922-2940. https://doi.org/10.3390/ijerph110302922.

Bellinger DC, Burger J, Cade TJ, et al. (2013) Health risks from lead-based ammunition in the environment. Environ Health Perspect 121(6):A178-A179. doi:10.1289/ehp.1306945

Cao X., Ma L.Q., Chen M., Hardison Jr., D.W., Harris W.G. (2003) Weathering of Lead Bullets and Their Environmental Effects at Outdoor Shooting Ranges. Journal of Environmental Quality 32:526 -534.

Commission Regulation (EU) 2021/57 of 25 January 2021 amending Annex XVII to Regulation (EC) No 1907/2006 of the European Parliament and the Council concerning the Registration, Evaluation, Authorisation, and Restriction of Chemicals (REACH) as regards lead in gunshot in or around wetlands (2021) Official Journal L24, p. 19. https://eur-lex.europa.eu/eli/reg/2021/57/oj

Dermatas D., Menounou N., Dadachov M., Dutko P., Shen G., Xu X. \&Tsaneva V. (2006) Lead Leachability in Firing Range Soils. Environmental Engineering Science 23:88-101. 10.1089/ees.2006.23.88.

ECHA (2021) ECHA proposes restrictions on lead use. https://echa.europa.eu/-/towards-sustainable-outdoor-shooting-and-fishing-echa-proposesrestrictions-on-lead-use

ECHA (2021) ANNEX XV RESTRICTION REPORT - Lead in outdoor shooting and fishing. https://echa.europa.eu/documents/10162/da9bf395-e6c3-b48e-396f-afc8dcef0b21

Fäth J., Göttlein A. (2017) Comparative investigation of the metal leaching from conventional and alternative game shot in a percolation experiment. Allg Forst Jagdztg 188:222-232. https://doi.org/10.23765/afjz0002016

Fäth J., Feiner M., Beggel S., Geist J. and Göttlein, A. (2018) Leaching behavior and ecotoxicological effects of different game shot materials in freshwater. Knowl. Manag. Aquat. Ecosyst 419:24. https://doi.org/10.1051/kmae/2018009

Fäth J., Göttlein A. (2019) Assessing the leaching behavior of different gunshot materials in natural spring waters. Environ Sci Eur 31:57. https://doi.org/10.1186/s12302-019-0249-2

Grandy J.W., Louis N. L., George E. B. (1968) Relative Toxicity of Lead and Five Proposed Substitute Shot Types to Pen-Reared Mallards. The Journal of Wildlife Management 32(3): 483-88. https://doi.org/10.2307/3798926.

Hurley P. (2004) The Structure, Redox Corrosion, and Protection of Commercial LeadAntimony Shot. http://www.cylenchar.com/Article.pdf

Hurley P. (2013) Environmental Risks Arising from Changes in Ammunition Materials. http://www.cylenchar.com/ESCGA_Moscow As_Article.pdf

Kanstrup N., Thomas V.G. (2020) Transitioning to lead-free ammunition use in hunting: socioeconomic and regulatory considerations for the European Union and other jurisdictions. Environ Sci Eur 32, 91. https://doi.org/10.1186/s12302-020-00368-9 
ICD-10 Version:2019. The International Statistical Classification of Diseases and Related Health Problems. 10 ${ }^{\text {th }}$ revision. http://icd.who.int/browse10/2019/en

ICD-10:E83.1 Disorders of iron metabolism. ICD-10 Version:2019 http://icd.who.int/browse10/2019/en\#/E83.1

Kanstrup N., Thomas V.G. (2020) Transitioning to lead-free ammunition use in hunting: socioeconomic and regulatory considerations for the European Union and other jurisdictions. Environ Sci Eur 32, 91.http://doi.org/10.1186/s12302-020-00368-9

Kelebemang R., Dinaker P., Sehube N., Daniel B., Totolo O., Laetsang M. (2017) Speciation and mobility of lead in shooting range soils, Chemical Speciation \& Bioavailability 29(1):143-152, DOI: 10.1080/09542299.2017.1349552

Levengood J.M., Sanderson G.C., Anderson W.L., Foley G.L., Skowron L.M., Brown P.W., Seets J.W. (1999) Acute toxicity of ingested zinc shot to game-farm mallards. Illinois Natural History Survey. Bulletin 36: 1-36

Lewis J., Skyllberg U., Hägglund L., Sjöström J. (2011) Lead oxide and soil organic matter complexes dominate the speciation in the clay fraction of bullet-contaminated shooting range soils, as determined by EXAFS analyses. Pedologist, 2011, 156-161.

Lin Z. (1996) Secondary mineral phases of metallic lead in soils of shooting ranges from Orebro County. Sweden Environmental Geology 27:370 -375.

Lisin V., Chizhikova V., Lubkova T., Yablonskaya D. (2020) Management of Environmental Risks Related to the Use of Lead Ammunition at Outdoor Sports Facilities (Shooting Ranges) Guidelines on the Best Available Practices. https://echa.europa.eu/documents/10162/7218926/10_lead_workshop_d2s1_outdoor_sport_r isks_management_issf_en.pdf

Lukina E.A., Dezhenkova A.V. (2015) Iron metabolism in normal and pathological conditions. Klin Onkogematol. 8(4): 355-361

Mateo R., Kanstrup N. (2019) Regulations on lead ammunition adopted in Europe and evidence of compliance. Ambio 48(9): 989-998. doi:10.1007/s13280-019-01170-5

Mera M.F., Rubio M., Perez C.A., Galvan V., Germanier A. (2015) SR $\mu$ XRF and XRD study of the spatial distribution and mineralogical composition of $\mathrm{Pb}$ and $\mathrm{Sb}$ species in weathering crust of corroded bullets of hunting fields. Microchem Journal 119:114-122.

NIST Critically Selected Stability Constants of Metal Complexes Database Version 8.0. User's Guide (May 2004) https://www.nist.gov/system/files/documents/srd/46_8.pdf

Okkenhaug G., Gebhardt K.-A.G., Amstaetter K., Bue H.L., Herzel H., Mariussen E., Almas A.R., Cornelissen G., Breedveld G.D., Rasmussen G., Mulder J. (2016) Antimony (Sb) and lead $(\mathrm{Pb})$ in contaminated shooting range soils: $\mathrm{Sb}$ and $\mathrm{Pb}$ mobility and immobilization by iron-based sorbents, a field study. Journal of Hazardous Materials 307:336-343.

Open Letters from The European Scientists on The Risks of Lead Ammunition. (2018), (2020) http://www.europeanscientists.eu/

Orlov Yu.P., Govorova N.V., Lukach V.N., Baitugayeva G.A., Klementyev A.V., Kakulya Ye.N. (2020) Iron metabolismin conditions of infection. Review. Annals of Critical Care. 1:90-99. DOI: 10.21320/1818-474X-2020-1-90-99

Pain D.J, Cromie R.L, Newth J., Brown M.J., Crutcher E. Hardman P., Hurst L., Mateo R. et al. (2010) Potential hazard to human health from exposure to fragments of lead bullets and shot 
in the tissues of game animals. PLoS ONE 5(4): e10315. DOI: 10.1371/journal.pone.0010315.

Pain D.J., Cromie R., Green R.E. (2015) Poisoning of birds and other wildlife from ammunition-derived lead in the UK. In The Oxford Lead Symposium. Lead Ammunition: Understanding and minimising the risks to human and environmental health, eds. R.J. Delahay, and C.J. Spray, pp. 58-84. Edward Grey Institute, The University of Oxford, UK.

http://www.oxfordleadsymposium.info/wpcontent/uploads/OLS_proceedings/papers/OLS_proceedings_pain_cromie_green.pdf

Pain D., Mateo R., Green R. (2019) Effects of lead from ammunition on birds and other wildlife: A review and update. Ambio 48:935-953. https://doi.org/10.1007/s13280-01901159-0

Paulsen P., Sager M. (2017) Nickel and copper residues in meat from wild artiodactyls hunted with nickel-plated non-lead rifle bullets. Eur J Wildl Res 63, 63. https://doi.org/10.1007/s10344-017-1123-4

Popov V.V. (2020) Soil solution and the methods of its investigation. The Journal of Soils and Environment, 3(1):e106. http://doi.org/10.31251/pos.v3i1.106

Rauckyte T., Zak S., Pawlak Z., Oloyede A. (2009) Lead leachability from shooting range soils. Ecological Chemistry and Engineering A 16(4): 419-426.

Rooney C.P., McLaren R.G., Cresswell R.J. (1999) Distribution and phytoavailability of lead in a soil contaminated with lead shot. Water Air Soil Pollut 116:535-548.

SAAMI (1996) Lead mobility at shooting ranges. Sporting Arms and Ammunition Manufacturers' Institute. 498 p.

Scheuhammer A. M., Norris S. L. (1996) The ecotoxicology of lead shot and lead fishing weights. Ecotoxicology 5(5):279-295.

Schwarz D., Fäth J., Göttlein A. (2015) Development of a standardized test method for investigating the environmental solubility of metal ions from materials used in rifle bullets. AllgemeineForst und Jagdzeitung 186:175-187.

Tarasova N.Ye., Teplyakova Ye.D. (2012) Ferrokinetics and the mechanisms of its regulation in human organism. The Journal of Fundamental Medicine and Biology 1:10-16.

Thomas V.G, Guitart R. (2013) Transition to non-toxic gunshot use in Olympic shooting: Policy implications for IOC and UNEP in resolving an environmental problem. Ambio 42:746-754

Thomas V.G. (2016) Elemental tungsten, tungsten-nickel alloys and shotgun ammunition: resolving issues of their relative toxicity. Eur $J$ Wildl Res 62, 1-9. https://doi.org/10.1007/s10344-015-0979-4

Thomas V.G. (2019) Chemical compositional standards for non-lead hunting ammunition and fishing weights. Ambio 48, 1072-1078. https://doi.org/10.1007/s13280-018-1124-x

Thomas V., Kanstrup N., Pain D. (2021). Promoting the Transition to Non-Lead Hunting Ammunition in the European Union Through Regulation and Policy Options. Environmental Policy and Law. 51. 1-16. DOI: 10.3233/EPL-201068.

UNEP (2007) The Strategic Approach to International Chemicals Management (SAICM). https://www.unep.org/resources/report/strategic-approach-international-chemicalsmanagement 